Portland State University

PDXScholar

$5-1-1970$

\title{
A proposed guidance program for Vietnamese high schools
}

Tran Thi Thanh-Tan

Portland State University

Follow this and additional works at: https://pdxscholar.library.pdx.edu/open_access_etds Let us know how access to this document benefits you.

\section{Recommended Citation}

Thanh-Tan, Tran Thi, "A proposed guidance program for Vietnamese high schools" (1970). Dissertations and Theses. Paper 931.

https://doi.org/10.15760/etd.931

This Thesis is brought to you for free and open access. It has been accepted for inclusion in Dissertations and Theses by an authorized administrator of PDXScholar. Please contact us if we can make this document more accessible: pdxscholar@pdx.edu. 
AN ABSTRACT OF THE THESIS OF Tran Th1 Thanh-Tan presented May 27, 1970.

T1tle: A Proposed Guidance Program for Vletnamese High Schools

APPROVED BY MEMBERS OF THE THESTS COMMTTTER:

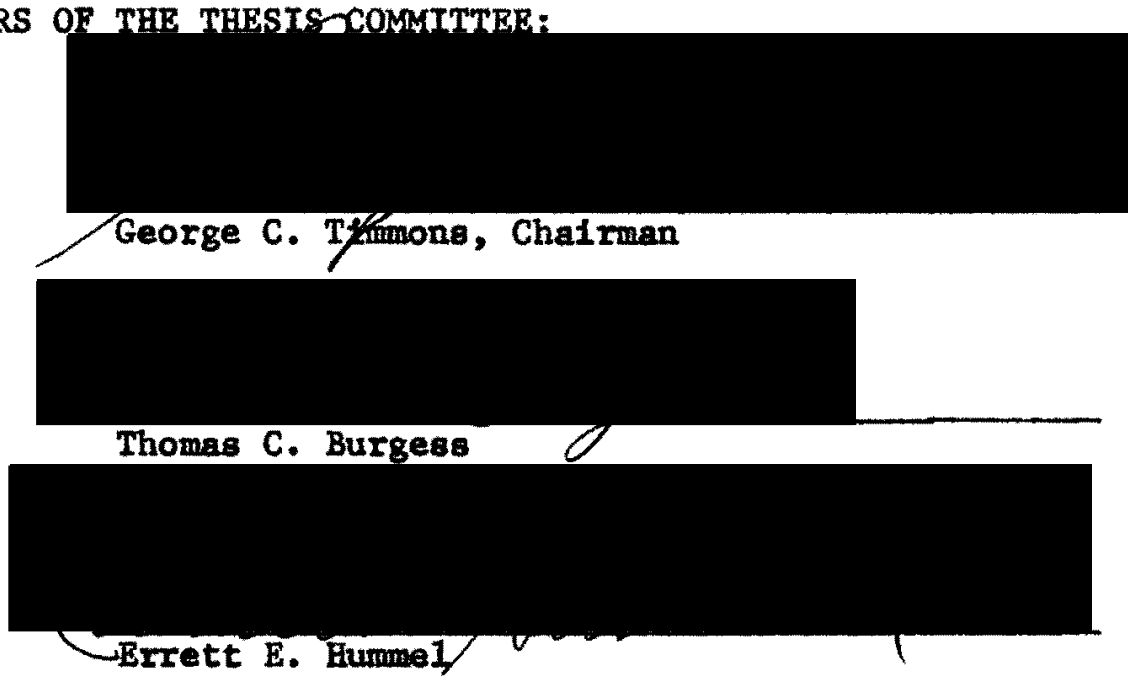

The writer has proposed a practical guldance program for Vletnamese high schools. The study has been written while education In Vietnam is in a period of revolution. Radical changes have been undertaken to keep up the natlonal demand for progress and economical self-independence. The need for guldance services in hIgh schools is necessary to promote learning toward better achievement and more logical training of manpower and social adjustment.

The traditional Vietnamese school, Influenced by thousands years of Confuctan concepts and hundred years of French culture, has been 
Ineffective in providing competent scientific and technical personnel, desplte a world moving toward rapid changes in industry and economics. Under theee conditions, the Vletnamese student encounters a puszling challenge; he is unable to adequately aseess his individual ability and emotional problema. Conditioned to memorlation, the VIetnamese atudent is unable to think for himself in order to find an adequate solution for his own difficulties. The contact of the real world of technique makes him feel lost and unable to choose the right way to learn, th1s euggests a vital need for soweone to gutde him through the mase of education.

The writer has tried to asalst the Vletnamese student in high school through the development of a guldance program which provides for the student, opportuntties to explore and to discover who he to and what he could do best. The student in this program will have avallable a counselor to whon he can turn for advice and assistance in developing a future program. Self-understanding w111 be emphasized which, hopefully, will lead him to self-acceptance, better achlevement, and preparation for entry Into a frustrated society and the world of work. In this study, differences in culture, social structure, local conditions and affects of the war have been analyzed, interpreted and brought Into discusalon. Different guldance services to implement the maln objectives have been proposed with enlightened perspectives. The role of the future counselor has been well-defined for clear-cut understanding. Hfs knowledge, abllity, and cepablilty to deal with youth problem as well as his responslbilltles have been recomended. 
His relationships with other guidance personnel and community have been clearly Iimited.

The proposed guidance program in this etudy will certainly have to be complete by further suggestions and recomendations. 
TO THE OFFICE OF GRADUATE SIJDIES:

The members of the Commltee approve the thesis of Tran Thi Thanh-Tan presented May 27,1970 ?

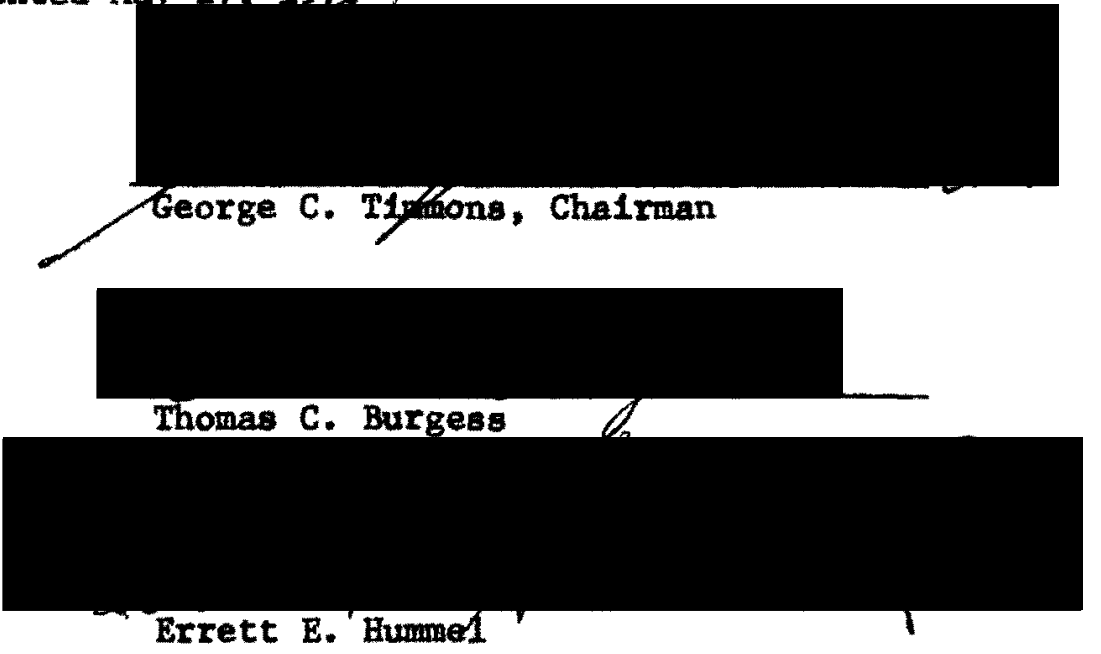

APPROVED:

W1ILam A. Jenk1ns, Dean, School of Education

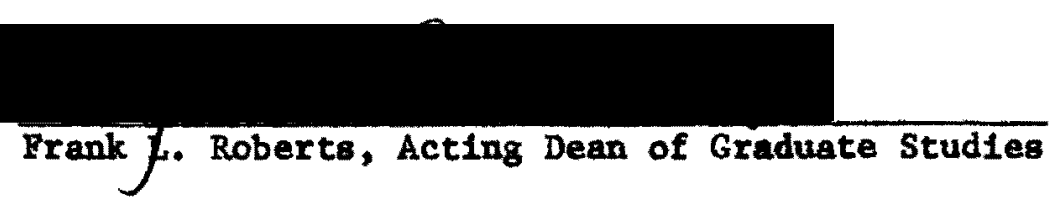


A PROPOSED GUIDANCE PROGRAM FOR VIETMAMESE HIGH SCHOOLS

$$
\text { by }
$$

TRAN THI THANH-TAN

A theals subratted In addition to the requirements for the degree of

\author{
MASTER OF SCIENCE \\ In \\ EDUCATION
}

\title{
Portland State University \\ 1970
}


TABLE OF CONTENTS

PAGE

ACRROHLEDGMRETS . . . . . . . . . . . . . . . 111

LIST OF TABLES ......................... v1

LIST OF CHARTS .......................... v11 CHAPTER

I IMTRODUCTION ................... 1

statement of the Problem ........... 2

Gathering Data and Procedures ........ 3

Limteation of the study ............ 3

II PHHOSOPHY OR EDUCATION IN VIETRAM .......... 4

Traditional Concept of Education ....... 7

Prench-Influenced Concept of Education . . . . 11

New Concept of Education . . . . . . . . 13

III ANALYSIS OF TEE PROBLEM OF GUTDANCE IN VIETMAMESE

HIGH SchOOLS . . . . . . . . . . . . . 21

The Present System of Education in High Schools. 21

The Curriculum . . . . . . . . . . . 21

Unpractical Goals of Education........ 28

Lack of Adequate Teacher Traintng . . . . 30

Attitudes and Responsiblittes of Teachers

Toward Students . . . . . . . . . 32

The Need for a Guldance Program . . . . . 35

H1gh Parcentage of Dropouta . . . . . . 36 
Brief Elstory of Guldance . . . . . . . .

Increased Need for Better Achlevement in High

Schools . . . . . . . . . . . . 44 44

IV A PROPOSED GUIDANCE PROGRAM FOR VIETNAMESE HIGH SCHOOLS - 45

General objectives ........... 45

Procedures .............. 53

Organization of Basic Guldance Services . . . . 53

Counseling . . . . . . . . . . . 54

Appraisal . . . . . . . . . . . 56

Ortentation ..................... 57

Placement . . . . . . . . . . . 58

Follow-up ................ 59

Evaluation of the Guidance Program at the Thu-

Duc Demonstration HIgh School ....... . . 62

S1gnificant Resulta............. 62

Polnts of V1ews ............... 65

V RECOMMENDATIONS FOR IMPLEMENTATION OF PROPOSAL . . . . 72

Additional Funds for Starting the Guldence Program .72

Tralning of Counselors ............ 73

The School Nurse . . . . . . . . . 76

The School Soclal Worker . . . . . . . . 77

The Psychologlet . . . . . . . . . . 78

The Claseroom Teacher' B Role in Guldance Program . 79

Differences Between the Guldance Functions of

Teacher and Counselor .......... 79

The Counselor Role . . . . . . . . . 81 
Organization of Guidance Services ....... 89

First stage ............... 89

second stage............... 92

Third stage............... 92

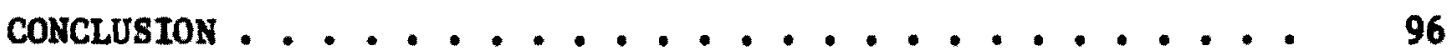


v1

\section{LISTS OR TABLES}

\section{TABLE}

PAGE

I Weakly Schedule for Vietnamese Sentor HIgh School . . . 23

II Secondary School Enrollment and Secondary Teacher

Tralning .................. 32

III Improvement of 43 studente in An Experimental Guldance

Program at the Thu-Duc Demonetration School . . 66

IV Follow-up on Elght Individual Studenta Who Falled Four

or More Subjects at the Thu-Duc Demonstration

School ................... 67 


\section{LIST OF CHARTS}

I General secondary School Teachers . . . . . . . . 33

II Pattern of All Secondary School Dropouts in 1962-1969................ 37

III Rate of Increase In School Population From 1961-1962 1965-1966..................

IV School Enrollment Compared With Total Age Population In 1965-1966.............. . . . 46

V Organdzation of The Thu-Duc Denonetration School . . 64

VI Organization of Guldance Services in HI'l School:

F1rst stage . . . . . . . . . . . 91

VII Organtzation of Guldance Services in H1gh School:

Second stage............. 93

VIII Organization of Guidance Services In High School:

Th1rd stage ................. 
ACKNOWLEDGMENTS

I feel deeply Indebted to Dr. George C. TImong, Asaistant Dean of School of Education, whose continuous advice has been Invaluable help to me.

I wish to express wy profound gratitude to Dr. Thomes C. Burgese, Coumselor and Assoclate Professor, and Dr. Errett B. Hummel, Professor of Bducation, whose preclous assistance have brought this study Into reality.

Thanke and appreclations also go to all the staff of the School of Bducntion of Portland State Univerefty for thelr courteous help during uy etay at Portland, Oregon.

Apprectation is atncerely expreseed to personal friends for the materials used for this study.

Obviously, I could not onlt to dieplay here my love and plety to py parents and isters, whose Immeasurable eacriflces have been a source of encouragement to py perseverance of work. 
CHAPTER I

\section{INTRODUCTION}

The Republic of V1etnam has long been the focus of foralgn observers for 1 ts frontless battle flelds. From the top point of Camau to the dellmitarized zone of Banhal, from the East Coast to the Vest boundary wth Laos and Cambodia, from the small hamlet oncircled by a bamboo hedge to the overcrowded capital of Salgon, the sporadic storms of the war have been tearing off what was built centurtes ago. As naver known before in 1 ts history, Vietnam ironically has been the stage for 1deological and technical experimentation of conflicting powers. Immense are sufferings, losses, destruction and disturbances. Nowhere is secure and threet of death is everywhere.

It has been wiraculous that iffe continues on this ting land after three decades of shelling, bowbing and killing. Life not only refuse to be extingulshed, but struggies for survival and reconstruction for progreas have been promoted right behind the scene of 11ghting. That occurs because the population does not cease to exist and to grow. Different social activities then continue to deploy effort and courage in watntaining the national heritage from total destruction.

In the field of education, some attention has been paid to bullding claseroom, training teachers and 1mproving curriculum in order to keep up the conetant pressure of the increating echolar 
population. However, confined in its traditionel she1ls of customs and beliefs, the Vietnamse aducation system has been stationary and hesitates to undertake radical changes for modernisation. The present day-to-day student has been ignoring that he is a human balng worthwile of pore consideration and that new hor1sone of a future life could be reached within his arwe.

The present etudy proposes a program for practical application of the principles of guidance in vietramese high echoole.

The guldence concept has been introduced to V1etnam efnce 1959 and auldance and Counseling progran has been experimented wh th the Thu Duc Demonstration School in Vietnan. Tentative plans have been made to generallze application of the program in all the future comprehenatve schools. These are tranaformed from the claseleal curriculum schools.

Th1e study w111 furnish materiale not only for the newly-born comprahenalve schools but aleo for all V1etnamese traditional schools which for one or another, are not ready to perform the new curriculum designed for them.

Included in thle etudy are:

1. A brief review of the background of the traditional ph1losophy of education.

2. An analyels of the present ituation wh1ch V1etnamese high achool students have been provided for learning.

3. A proposal of guldance program in high school with enphase on the role of the future counselor in the 
frame of a soclety in course of development and in

which traditional concepts of 11 fa should be taken into account.

4. Recomendations and implementetion for realising the program in conditions offered by the communtty.

The sources used in this study have been collected according to their degree of accuracy, validity and up-to-date and then analyzed, interpreted, and referred throughout the study.

Th1s otudy has been restricted in 1 ts pupposes by the lack of avallable materials on the progress of the present educational syeten In Vietnem and the Ignorance of developing peychological favor among parente for such a program at the Thu Duc Demonetration school. 


\section{CHAPTER II}

\section{PHILOSOPHY OF BDUCATION IN VIETMAM}

Education in Vietnam has long been criticized, diecussed, analyzed, and revised for many yeara without any lgniflcant change in 1ta fundamental etructures. Facing an Increasing need for high ablifty manpower for national development, the present educational syetem of Vietnam is in constant crisis. Under the preseure of the war, education has recelved for yearo a low-natlonal priority. Only f1ve percent of the national budget has been allocated to education. 1 As a result, pervasive chaos has been found in primary and aecondary education. From the countryalde to the capltal, youngstera of elementary and secondary echool age recelve far leas than a modern education. Clase size often exceeds the government' official limt of 50 pup1ls although only 70 percent of the elementary school age and 17 percent of the eecondary school age youngeters are reglatered in schools.2

Poor equipmant 1s another problem of the education criels. W1th the a1d of forelgn governmente, millions of taxtbooks have been printed to provide every elementary school pup1l a complate oet of modern texts, but for a curriculum established wny decadea ago. The

1"Schools in V1etnam," Newroreek, (August 28, 1967) 55. 2 Ib1d. 
shortage of butldinge in Salgon and other cltles places many schools on four-hour shifte and thu a number of subjects are cut down. The weakest part of the educational gyetem in V1etnom is the lack of trainad teachers. Forty percent of the elementary teachers have had no formal tralning. Many have completed no wore than the fifth or the alxth grade. 3

The present elementary and secondary curriculum, carried out at nationwide scale, was designed by the National Ministry of Education years ago and emphealzed academic and theoretical performance rather than technical and vocational training. Thounands of high school graduetes are not assured of finding jobs even though unproductive government jobe are avallable each gear. The vast majority of V1etnamese are engaged in agriculture but this is not reflected in the $\times$ curriculum. The rural people who would profft from vocational rather than acadentc training never recalve $1 t$.

Opportunities in Industry and the professions are also restricted by the poor technical vocabulary in the Vietnanese language. French has been the languaged used In technical and scientific training. According to Jack M. Patt ${ }^{4}$, In certain faculties at the Univereity of Salgon, a few subjects are taught in Vietnamese. However, VIetnanese 10 used only in the preparatory year, after which the student must use Franch. Every subject in the mathematics and phyolcs courses is taught In French, even In the firat year. In the technical colleges,

\section{Ib1d.}

4"The Language D1lemma In VIetnamee Educution," Journal Btgher Bducetion, 200xx (May 1969) 388. 
and In the Animal Husbandry School, the Prench language st111 plays the dominant role.

The matn reason for using forelgn language in higher education 1s that VLetnamese teachers trained in a foralgn langunge have found 1t eavier to teach in that language then in their mother tongue, and 80 percent of the textbooks in use are written in foraign languages. 5 Although Vletnamese is capable of expressing accurately specialized and technical vocabularies by incorporating and converting them to a phonetic tranecription in Vietnamese, many university professors are against any change for the development of the required technical vocabulary in national languege.

The Vletnamese from lower achools, who, for lack of language fluency, often fall to complete their university studies, have supported a movement to make Vletnamese the language for all levels of education and popular pressure for changes in the educational syetem has urged the government to bring an adequate colution to the present dramatic crisis in education.

Another 1mportant challenge that atudente In h1gh school are In great embarrasenent over is the cholce of aubjecte when entering the tenth grade of the sentor program. They heve no guldance service to help them make a desirable decision to follow one of the four poselble curriculum tracke: Sclences, Mathematics, Forelgn Language and claselcal languagea. All four of the approved curriculum tracks are almed to prepare the succeseful student for admission to the undversity, yet 86 out of 100 fall every year in attempting to secure

${ }^{5}$ Ib1d., p. 389. 
a baccalaureate II degree (high school graduation). What happens to the large percentage of students who fall to complete the sentor high 8chool program? Unfortunately whthout thls degree they are not accepted for any of the more desirable jobs.

V1etnan could profit the most by enriching its own culture through selecting and Integrating the wost brillient and adequate features of both Rastern and Western educat1onal systems. To we, Introducing guldance and counseling into vietnamese high achools might be a way out of the present criels. It ie a new fleld the American schools have had long experfence with and a great deal of its effectivenese has long been demonstrated. W11l the principles of guldance and coumseling be applicable to the present altuation In V1etnam? The V1etnamese scholexe would show considerable opposition to it as they have been used to belng skepticul about proposed solutions influenced by foreign cultures. But a deeper exmmatnation of the matter based on facte and clear-cut results wht persuade them to give favorable consideration and to approve for adoption guidance program in V1etnamee high schools.

\section{TRADITIONAL CONCEPT OP EDUCATION ?}

Before undertaking the discusaion of an adequate guidance program In this brief study, it is necessary to look back to the h1story of education in VIetnam. Retablishing a new concept of education needs to be based on the established philosophy and to be consietent with it. The period of Chinese dowination was interrupted many times by 
by several such 1neurrections for independence. In general the Chinese domination was the long night of V1etnum's history--a night of ten centuries long, "during which Chinese civilization becane deeply rooted In the country." 6

The Influence of Chinese civilisation has matntained a strong Influence over the V1etnamese culture from the tenth century to the present. Thls Influence has long been an obatacle to progress by exphasizing literature and h1gh social ranking over technical and practical activities. The scholars who went to school for years were 11kely to seek for respect and position in society. They considerad laborers as despleed, lower, and eervile cltizens.

This rush to high social ranke and unpopular attitudea toward the peasantry clags has derived from Confuclaniam wh1ch gave highest place to the sholar in society. The alws of education were dictated by the political and eocial structure. The immediate purpose of formal training was to prepare young wen for the examinations through whtch they ught enter the mandarinate and open doors to privileges. Confuclan scholars vere supposed to be motivated by cultivation of high woral character, eopecially an apprectation of the riedom of the ancient aages of Chine and of Confuclan principle.

The program of atudy centered on the Confucian classics. Som courses on Chinese history, Vletnamese history, anclent poetry and military tactics were also taught. The language of instruction was

\footnotetext{
61etnamese Realities. Salgon: Mintetry of Forelgn Affalra, $(1967), 49$.
} 
written in Chinewe. 7

Formal training culminated in a series of rigorous competitive exaninations. In the oystem which prevalied in the late eighteenth and early nineteenth centuries, candidates for scholarly rank were eraminated firat in the provinces; then 1 succeseful, In the capital at Hue; and finally at the highest level, in the Imperial Palace. "These exminations took place every three yeare. successful cundidates, depending on which of the exeminations they paseed, became 10w- and middle- and high-ranking goverment officlals." 8 The Confucian concept of "Quan, su, Phu" or "king, Teacher, Father" which placed the teacher right after the kIng and before the father, has long bean taught to studente who used to over-reepect teachare to the point that they rarely contradicted the if they wanted to succeed.

This concept deprives the etudents in modern schools of the skill of criticiom and the ability to formulate an adequate judgment. He is likely to accept as true whatever the tencher tells him In the claseroom. BIII Raines, sesoclate profeseor of education in Vletan, recently conflrmed, "Vletnamase have long been taught to resrect and honor thelr teacher and they were too pollte to say anything oven mildiy critical of him." 9

7Harr1e, George L., et al., Ares Handbook for VLetnan, (Wachlngton, D.C.: P.S. Governnent PrInting Offlce, September 1962) 116.

\section{Erbid.}

9atnes, Bfl1, "Working as a Teacher Educator in a Developing Country," Ohio Ynivere1ty Contract USAT/Bducation Sent-Annual Report, (Janusry-June 1969) 126. 
The same factor influences the teacher's view of h1s classroom:

It strengthens the teacher's ego to be considered a fount of wladon who spenks that which students must write and repeat by rote. In his own 11ttle ephere, he, too, is a fuler. A change in the method of teachIng to wore active participation on the part of the student, encouraging the student to come up with new 1deas, even 1deas that contradict the teacher's. threatens this security. 10

Another consequence of the Confucien influence over V1etnsmese education of today is that atudents continue to choose careers as government officlale who hold both administrative and fudiclal powera over farmars, artienns, willtary and buelness men. They otill envy members of the powerful clase which has long been enjoying prestige and consideration. This misconcept leade studente to the neglect of technical learning of practical akille in a modern soclety. They would prefer belng a goverment officlal with a low aalary rather than belng a skillful worker who could earn much more money.

The learned man has not been a worker.

The Scholar could not engage in manual labor, and 1t was beneath his dignity to show a student how to do somethlug. He vould, however, present an elaborate explenation on how somethlng hould be done. Consequently educatlonal programe in the polytechnic arte and sciences have pever developed along with programs in the humanitiea. II

10Education V10tinen Proposale tor Reorganiration, (W1scons1n State Univere1ty: Stevene Polnt Study Tean, ADD, 1967) 135.

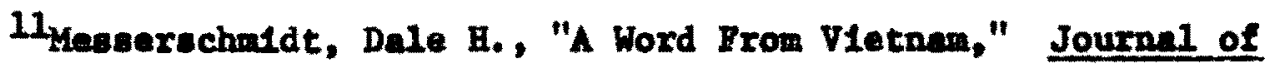
Industrtal Arto Edueation, xxvil (Auguet 1968) 35. 


\section{YRENCE-INTLUENCED CONCEPT OF EDUCATION}

Western learning, Introduced in Vletnem by French rulers in the nineteenth century, had been developing rapidly as traditional educution faded out. The French educetion led to the almot complete destruction of the mandarin eyotem (organization, examinations, etc.). The new French gyoten centerad around a amall "Gall1c1zed ellte" that was out of touch with the people. The deterloration was such that, on the eve of World War II, there were more priwone in Vletnam than achools.

The Prench aysten, Imposed by the colonial goverment, focused on the training of a restricted number of clerice, interpreters, and minor officials to eerve in the lower ranke of the colonial adninistration. All clesses were tuught in Fronch oven at flret grade level. In 19I1 the French authorities decided to set up a formal French aducation for the whole country, providing a uniform curriculim to all achools. At the ond of each cycle of studies, highly selective examinations constitutad a "barrage" for the average otudent. Blementary education, which covered a eeven-year period for children aged $81 x$ to 12 , was subdivided Into three and four year cycles, the flrat leading to a certiflcate of elementary studies and the second to a certificate of primary atudies. Secondary education was given In the lycees and colleges in the citles. Th1s program Included a four-year higher prinary cycle, leading to a diplowa of higher primary stud1es, and a secondary cycle of two years (after 1927, three yeara) which ended in an examination for the baccalaureate. 12

12 Barris, George L., et al., 115. 
The Univeralty of Hanol, the oldest unfversity in Vletnam established in 1917, mas ained to train h1gh-1evel administrative clerks. Later in 1930, by social dewands, this unfversity inftiated schools of medicine and pharmacy, pedagogy, fine arts, agriculture and cownerce. The teaching staff of the university was entirely Brench.13 The Inadequate French education contributed to the deficit of qualifled techniclane necessary for an underdeveloped country after World War II. The whole educational atructure, deslgned by French colonists, afmed to mat the needs for administrative personnel and to prevent political opposition rather then to provide an adequate practical education to the VIatnamese youth.

Today, after recovering national independence following nearly a century of struggle against French rulers, Vletnan has found grast diffleulty in bullding a modem soclo-economic structure, viaving the shortage of techniclang in all flelda. The influence of the French educational systen otill affected the Vietnamese schools af ter the Geneva Agreemente in 1954. The most pressing problen was that Vietnamese studente at the untversity level had been discouraged by the use of French language in technical and scientific flelds, and by the lack of V1etnamese textbooks in all branches of study. Many parents st11l belleved in the efflclency of the French aystem and forced thatr children to choose Prench as a primary forelgn Innguage In high school.

13 Ib1d. 
The need for techntcal and eclentific language is not the only dleadvantage of the educationel aystem. Other gaps to fulfill the objective to develop technical and vocational education are the lack of good vocational technicel teachera in junior profeselonal achools on one hand and an effective vocational guidence eervice in regular high schools on the other. Teachers in a few vocetional high Bchoole in Salgon need to be trained in teaching techniques and maintaln and update their akll1s and knowledge. By their poor quality of Inatruction, studnnte are unable to think creatively and they learn by rote menory or do profects designed or enlected by instructore. These etudants continue to manipulate inferfor quality equipment and tools wh1ch have no resemblance and relationgh1p to modern apparatus comonly seen in induatry.

These conditions seen to diecourage the youngeters in high schoole frow choosing vocational careers. In a country that is rapidly changting from an agricultural soclety to an industrial one, technical and vocational ak1lls becowe highly dealrable, but the high school curriculum doen not provide any guide toward that direction. Therefore, a guldance service for vocational occupation In high echool is vtal to catch up the national need for techniclans.

\section{NEW CONCEPT OF EDOCATION}

If the Confucten ph1losophy can be blemed for 1 te outmoded cultivation of high moral character to maintain the polltical otability of the feudal structure of the society, neither is the narrow-ainded 
concept of education brought in by French colonists appropriate for a young nation in constant development after many decades of stagnation. Aftex 1954, the date of political independence, the need for a new philosophy of education came into the mind not only of the author1t1es bearing responsibility in the field, but also of every one who concerned himself with the future of the country. A new ayetem of education has amerged from the polltical cheos and the confusion of the war. In apite of several reforms to adapt to changes in the polltical situation, the system cannot yet be called auccessful?.

A Figld curriculu designed a long time ago, severe shortages of elementary and secondary school teachers, lack of adequate textbooke and Instructional materials, crowded classroons, highly centralized control, and over all, a modest budget for an ambitlous program have contributed to winimize the desired results. Moreover, the growing school population, the continuous upheaval of the wer in the countrys1de, and degenerating mores and traditlons put the new system of education Into a real challenge. The governmant has made great efforts to make the aratem keep up 1 th the changlng st tuat1on and the need for progress. The common people often doubted the effectiveness of the present education and wondered whether 1 would be more valuable to bring a radically new concept into 1 t.

Hoang-GLa-LInh hes expreseed his anxiety on the prasent national syatem of education by theae words: 
In the present conjuncture, can we say with John Dewey that education must have an autonomous etatus and that "It could not be determined by coctal and political demande external to $1 t^{\prime \prime}$ or ohall we agree to some extent wth Hegel's theory of the state and of the duties of Individuals and lead our education toward tralning the adolescent to understand that "h1s soclety and his state imply a lerger whole, one that lies closer to the realities" and that he ahould "renounce himself, lenrn obedience and earvice to the soctal whole, and learn reverence for 1ts epiritual achievements"14

Many facts lead to the conclusion that in the case of Vietnam education cannot be set apart from the national struggle for aurvival, and theortes of education should be adapted to the present tragle eltuation. racing a constantly threatening forelgn 1deology and a total deganeration, education muet deal with the national policy to accomadate many aspects of the war, and contribute to a longranged planning for a post-war reconstruction and progreas. Linb wrote:

A philosophy of education appropriate to the present needs of V1etnam, remalns to be defined In clear term with a spectal emphasis on the preparation of the adolescent for citirenuhip. It hould glve priority to certain objective: whtch appear to be wost urgent: for example, education for public purposes against educetion for private purposes; education for the society agalnst education for the Individual's better living; education for secular purpose against educetion for religiou aims; education as a means to save the community one belonge to against education for knowledge as an and in Iteelf. 15

14 Hoang-Gia-Linh, "The Critical Stage of Education In Vietnam," National Eleaentary Principal, xilv (February 1965) 50.

15 Ib1d. 
Recently In a epeech delivered to the Vietnamese people, Nyguyen Van Thieu, President of the Republic of Viatnam, reasserted the bational pollcy of education as follow:

Wth epeclal regard to the educational field, which beare clear and strong influence upon socioeconomy. I have advocated the "policy of the Republic of V1etnan is to realise a eystem of mase and practical education." ... Every citizen had the duty to contribute actively to the educational program and has the right to benefit education at least to a basic level. Only then can we accompliah educational justice and promotion of the people' educational level in order to Improve the soclety and to dafend the national cause. That is also the opirit of democracy and equality achieved through the educational regime.16

In the purpose to oppose the former 11teraxy and non-realletlc educational progran, President Thleu pointed out:

Another important point in wy pol1cy is that the educational gyetem mut be orlented to prectical appllcation. Tht moane we have to euccessfully coordinate the two objectives of education; development of personal capability and adjustment of soclety. 17

The above statement of President Thieu cen be considered as a new trend of education almed to satiffy the need of a suttable ph1loeophy for a coumtry engaged in an endlees war for ourvival. His statement actually reflected the principal objectives of the education pollcy outlined in 1967 by the National Counc1l of Education. These

16 Myguyen Van Thleu, Bxcerpts, dealing with education from the opeach to the V1etnamese people delivered on October 6, 1969, mineographed.

17 rbid. 
objectives are based on three baelc princ1ples: humantem, opennese for other cultures and national feelings. This means:

Formation and uplifting of the human being and the citizen; active solidarity and affective service of the collectivity at all levels; denocratization of education, 1.e., equal chences for the younger genoration, in view of intellectual, moral, technical and social progress of the Nation. 18

To the point of view of the writer the national philosophy of educat1on, although conforming to the demand of a country in course of development and strugsle for Independence, seans to raflect a general 1ine of national policy and prest1ge rather then to clear up and enlighten the role of education in term of material and paychological concerns of the young school population.

That the school in aoc1aty is 1111 a place where the young atudents need to be underetood and to be helped has long been 1 gnored or afntmised. No help was provided for the youngster to guide hia way through the seven years of h1gh school. It appeared to we that the national philosophy of education should not onit the concept of "needs" of young atudents. It is unrealietc to etress the values and obligations of the human being on one hand and to undermine the Important aspect of thelr peychological needs on the other.

Dr. BIIl Raines, has given bastc principles to philosophy of guldance in which the needs of studente were emphesized. Three out

18 Report on the Progrees of Education in Vietnam During the school Iear at Xxxth Intermational Conference on Rublic Educatlon, Salgon: Minietry of Education, (July 1967) 8. 
of four asuumptions were accepted by Vlatnamese atudents and I think they could wall be lncluded in the new concept of national ph1losophy of education:

1. Rach child is an important and worthwhtle human being and 1s worthy of being treated with kindness, consideration and reapect. Bach means that there should be no exceptions, whether a ch1ld is bright or dull, rich or poor, and brightly wotivated or not.

2. Bech child to anique Individual with his own rate of development, 1ntellecturl capacity, level of achlevement and maturity. Therefore these differences should be expected, appreciated and provided for in the class room.

3. All human belnge have certaln comeon paychological needs. They need to be loved and accepted. They need to feel important. They need to experfence success in their endeavors. They need to be free from excessive fear and andety. 19

Inherent in these statements is the concept of Individualisation. The ch1ld must be considered as an Individual with his physical, peychological, intellectual and spiritual values. He has goal in his comunity and society. He has a responalbility to his fellow to act in a manner sympathetic to them. Otherwise, he 1s responsible

19 Ra1nes, B111, "A Guldance Ph1losophy for Teachers and Bducational Pract1ces wh1ch Raflect That Phtlosophy," Lecture presented to atudente of the faculty of Pedagogy, University of tue (Apr11 1969). atmographed. 
for h1s own action. His chlef hope is for comfort and ald in his own dectolon making to 11 ve hls own life as he exists in a world of reallty. But to fulfill his responsibllity toward his comunity, he should have the opportunities to choose wisely the direction in which he might reach the optioum development of h1s own ab111ty.

Thus the ultimate goal of counseling must be the freelng of the Individual child from obatacles, threata and "excesalve fear" of the reality to make his cholce, not to follow those made by "wiser" men.

If the ch1ld "behaves 1rrationally" or "cannot see reallty," It Is because he elmply is not both physically and paychologically free to behave otherwlse. Each child has a unlque "11fe space" which results in a particular set of personal values and strivings. And as no one can know all the meaninge of phenomena which affect his 11fe, no counselor can know him completely. Fortunately, the counselor needs not know all of the personal meanings of the child to ald him in becoming free to live his own 11fe-style. S1nce wen are somewhat similar because of their generic traits, and atnce the physical world is present to everyone, counselors can hypothesize and predict what the child might be expected to do. The above assumptions vould stress the Important position of the Individual student in the guidelines of a phllosophy of gutdance to be introduced in V1etnam. The young Vletnmese student is an Individual who has had habits of thinking and bellef Inherited from centuries of Chinese and French Influenced culture. He is living in a soclety in great disturbance but in 
ascendance toward progreas. He should be provided tools and skills to 11ve in a modern society in the future. As his nation has chosen freodom and democracy over despotian, hie personality ohould be respected as a humen being with his traditional values. The education he recelves in the claseroom mast be fitted to his own life, to his own enviroment, otherwise Individuallzed. The achool muet give hlm advice and help to pursue his own goal of gelf-realization in Instruction. Th1s w111 be discuseed largely in Chapter III. 


\section{ANALYSIS OF THE PROBLEM OF GUIDANCE}

IN VIETHAMESE SECONDARY SCHOOLS

I. THE PRESEMT SYSTEM OF EDUGATION IN SECONDARY SCHOOLS

\section{The Curriculum:}

Since the Geneva Conference in 1954, South VIetnam has been polltically "Independent" and has declded to change radically the old French education system into a national syatem of education. The Secondary Education Reform, Introduced new curriculium into every econdary school.

The purpose of the new structure 10 to give the junior high school studentb, who form the majority of the scholar population, a rastricted but falrly complete aducation which w11l serve as basic knowledge to them when they leave the funtor h1gh school for 11 fe. Those student who attend the senfor h1gh school recelve more adequate education for higher otudies in universities.

The funlor h1gh school Includes work in V1etnamese hlatory and geography, cIvics, physics, chemistry, natural sciences, mathematics and the study of a preferred forelgn language (Englith or Prench), phyeical education, and domestic sclence and child care for girls. The Jundor high school leads to the exumination for the certificate of etudies for the f1rst cycle. Pup1ls who pass the examination 
given at the end of the firat cycle can be admitted to the eecond cycle.

During the sentor school (10th to 12th grades), students heve to concentrate on one of four flelds: experimental sciences (Section A), wathematica (Section B), modern Inguages (Section C), and claselcal languagee (Section D). Table I show the main differences In the major and winor flelde of each section with reapect to the number of hours of each oubject taught in cless.

After the eleventh year of high school, the student 18 qualified for an exanination known as the Baccalaureate I (fIrst part). Only If he bas passed this examination cen he be adnitted to the final year of high school. At the end of the flnal year be may take the exnmnation for Baccalaureate II (second part). The Beccaleureate II Is the key for entrance to different institutions of higher education, to milltaxy academies, to high-level clvil aervice occupations and to other good jobs. But the exminations are difflcult and highly aelective. In $1960^{1}$ only about one third of the candidates pased the f1rat part of the becceleureate, and only slightly more than onebalf of this renalning group passed the second part. The wajor cause of fallure is probably atudents have chosen the wrong eection by Ignorance of their ab1lity on the fleld or by pressure from parenta.

The main characterletic of such a curriculum to that wen the atudent chooses an academic fleld, he virtually neglects all atudy In

1George L. Herris, at al., p. 117. 
TABLE I

WEEKCY SCHWDULE FOR SECOND CYCLE (SENIOR HIGE)

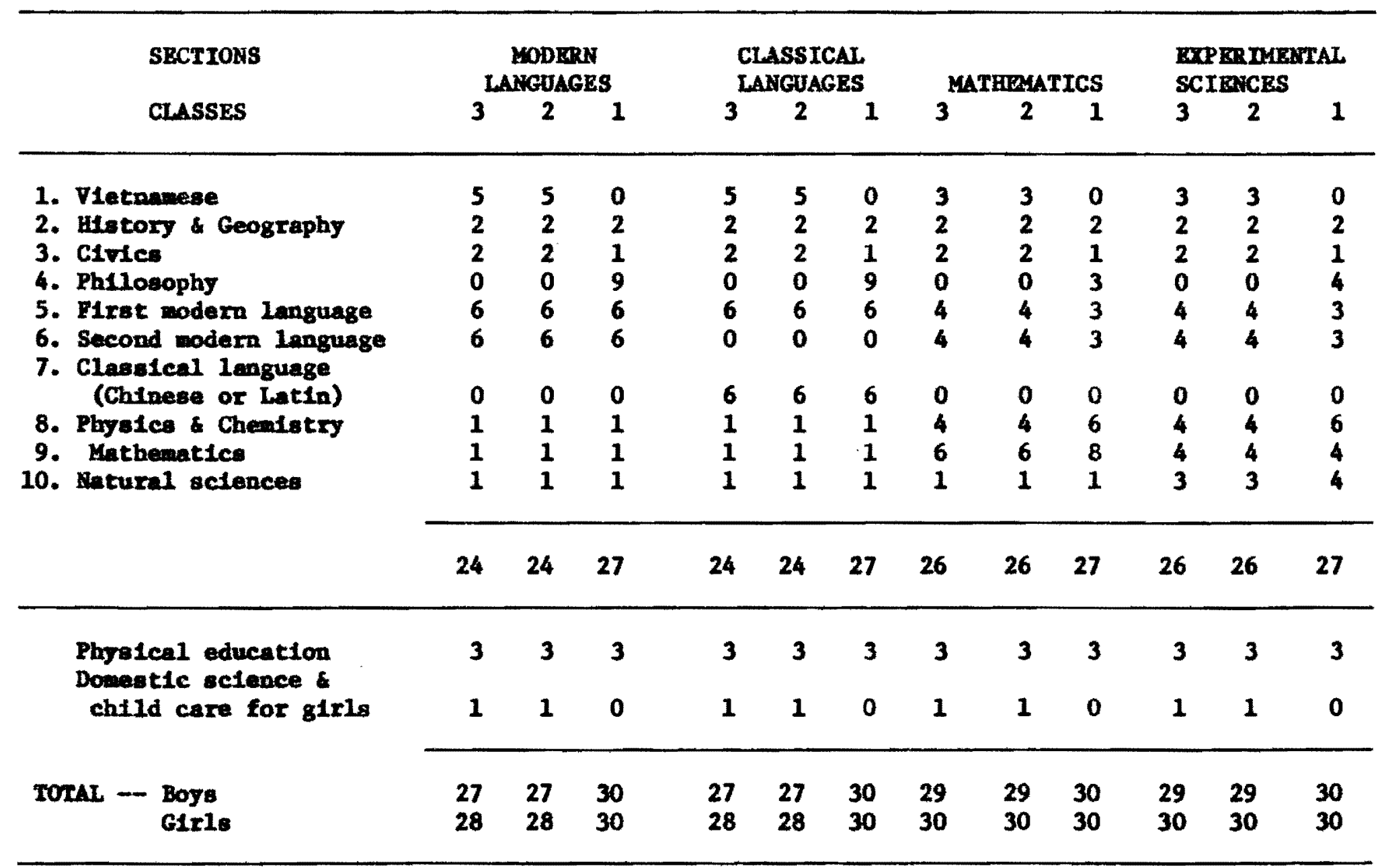

3rd, 2nd, let grades corresponding to 10th, 11th, 12th grades in the United States. 
other areas, 1ike, a student of experimental sciences section hes 11ttle to do wth modern language. Is a consequence, when he graduates, he w11l be unable to do rasearch in the rich techntcal waterials offered only in forelgn languages such as French or Rngl1sh, nor cen he follow meaningfully lectures provlded in foreign languages as in the Faculty of Medicine.

Another weakness of the curriculum is 1 ts ineffectivenase in providing studente with opportunity for open-ainded Individuality, exploration and self-evaluation. They quite often vrite down the lecture and try to monorize the notes. Rarely they are Invited to d1scuse, to ank questions, to explore and to draw meaningful conclusions. The teacher, traditlonally lectures, wakes occasolonal demonetrations as in sciences class, and malntalno a certain diatance between bimelf and the students. He is too concerned with the 21 gld curriculum he hag to flnish at the end of the cycle to be concerned Wth whether or not students participate in the classroop. As the educational gstem is highly centrallad, the curriculum, deslgned at the national level, is expected to be reupected and to be applicable for all studente of all areas no matter how different their mode of living or enviroment. Throughout the country, teachers are required to follow the natlonal curriculum in order to keep intact the national Inage of the classroom. This tendency to have everything follow an exact national picture "1s one of the thinge that most 1colate the nation and national education from the people and allows 
them to think that it is not really 'their' government and 'thalr' school." 2 It falla to produce productive and contributive citiaena wth epecial akille to bulld wodern and induetrlallzed country. Originally conceived by French-influenced intellecturle, and for city shools, the curriculum is outdated and because of the national examination gaten, it cannot be 1mproved by Individual or regional authorities for the profit of students, nost of whon live In the country or by the sea. In other words, for the fifteen yeare between 1949 to 1965, the national curriculum only net the needs of barely one percent of the school population ${ }^{3}$ and was merely a preparation for the univeralty.

Under the pressure for change in 1965, many efforts bave been made by responeible authorities to revise the curriculum. A comaseston for Improving Education and numerous curriculum study committees heve been set up to consider the problem. In the same year, 150 to 200 teachers $^{4}$ from all levele and spheres of education, public and private, worked with experts, consultants and advisors from forelgn miselows and charitable organisations for two weaks to bring an adequate change to the eyllabus.

2Education Vietnam Proposals for Reorganization, p. 140.

3"V1etnam: Bducationel Developmente in 1964-1965," International Yeerbook of Bducation, xavil (1965) 339.

4 Ib1d., p. 341. 
Topics discuseed, analysed and solved included: a tentative groupling of related subjects, date at which specialization should start, and the amount to be taught to each age-group; posalbility of working and applying a differentiated curriculum to weet the noade of studente living in four completely different geographical areas (c1ty, coumtry, h11ls, coast), whether general aducation should stop at the age of 15 (and of the ninth grade) for soclo-economic reasons, and whether sclence ohould be taught eeperately. 5

Th1s National Convention for Inproving the curxiculum, has consiatently promoted the trend toward simplification and practical application, combined with the principles of axternally Impoeed diecipline and social service.

To reaseas the pup11's work, and to de-emphasise examinationcentered learning of high school atudents, national examinations prtor to the baccelaureate were on November $30 \mathrm{th}, 1965^{6}$, these ware abollohed for all pupila attending school regularly. However, the f1rst part of the baccalaureate examination was malntained temporarily to deal with military reserve officer training which requires the level of the corresponding hIgh school 11th grada. The sane applied to secondary school entrance examinations which will be abolished wen claseroom and teachers can be provided to all elementary graduates according to the compuleoxy education law.

\section{SIb1d}

6"Republic of V1atnam: Bducational Developments In 1965-1966." International Iearbook of Education, xxi11 (1966) 401. 
In the fleld of guidance, In June, $1966^{7}$, the Minister of Education began encouraglng the work of oome specialists in developIng peychological test suttable for the VIetnamese and applying test reoult In all of the achoole from elementary levels to the untversit1ea; this guldance will be applled in the future comprehenalve schools.

Dur1ng two decades from 1949 to 1969 great efforts have been made on the part of the govermment to reform the obsolete PrenchInfluanced syotem of education. But no long-range and adequate goals have been ectabliohed. Token changes seemed merely to nand a narrow and old cloth no longer fltted to a growing adolescent. To contain the preseure for radical changes, succeselve governmente undertook but hesitating and Indecialve stepe toward eatablightng a well-balanced and modern gyetem of education. The maln raason for failing to prowote sound changes and to deternalne strong goals may be that reaponstble authortties in education have been clinging to acadenic values they acquired from the French system which exphasized memorlaing verbalized generalization rather than practical knowledge. Descendente of privileged famdlea were the only few students who could go abrond to afford a high education in a French university. As they returned to the fatherland with a high degree, they ware highly regarded and occupled key positions in the soctety. In epite of the dewocratic spirtt they asedatlated in forelgn countries, they conaldered themselves as the most aducated men and formed a clase apart

$$
\text { 7rb1d., p. } 402
$$


from the people. Thay ware unlikely to work for the benefit of the people and were atubbornly opposed to any change which would compromea their personal intereste.

Unpractical Goal of Education:

Responstble for Improving the whole educational syetem, these leadere were setting up unpractical and unrealistic goals. The tendency toward a traditional 11taracy atill pervaded the curriculua of different levele in epite of many reform. Vague goals were atated at each phaee of development but 11ke fall leaves, they died after beting iseued in a hurry. While setting up goals to denl with the 1tuation, V1etnamase educators atned to satiafy a politfoal demand rather than to weet a national need, Sophisticated statements have been created, but inefflctency and bureaucratic red tape deatined them to fallure and a new criale. It seemed that the following factore vere not taken seriously into account to establioh valld educational goale:

1. the objectives should be baeed on eclentific research in torms of natural resources, manpower and economic development.

2. changes in the program of education should be deternined at autebla rate to avoid confusion and frustration.

3. the educational ayeten should be considered as a wole wth 1to interrelationsh1ps, and changes should not be undertaken in separated areas. 
4. professional performance should be evaluated on the basis of achlevement rather then on the basis of political Influence. Incompetent and Inefficlent personnel should be replaced and not tolerated in order to reach stated gosis.

5. changes should be aimed to meet the real national noeds, rather than for the purpose of publicity or political contro1.

The lack of conideration of the above factors might lead to many problems that the government vas unable to solve. Por Instance, In $1965^{8}$, a f1ve-gear plan for the development of education was worked out by the Ministry of Bducation and adopted by the Covernment. Among the main objectives were: (1) In five years' time, 40 percent instead of 20 percent of the ch1ldren who complete their primary schoolIng can be admitted to public secondary schools; (2) In five years, 1,200 secondary school teachers Instead of 300 w11 be trained every year.

It 18 worth noting that in 1970 , flve years after the eleborated plan, the primary pup1lo will pase from $1,662,000^{9}$ to $2,097,105$ Gearly Increase of five percent). Forty percent of this population would be 838,840 and would need 16,777 secondary teachers. Unfortunately the number of secondary teachers $\left(2,450\right.$ in $\left.1965^{10}\right)$ could never keep up

\footnotetext{
8" Republic of V1etnam: Bducational Developments In 1965-1966," P. 398.

9Ib1d., p. 40

10 Republ1c of V1etnam: Educational Developmente 1964-1965. Intermational Yearbook of Bducation, p. 340.
} 
wth ouch a damand although a yearly increase of 1,200 secondery teachers has been visualized in the five-year plan in 1965.

Such an example would clearly 11lustrate the carelessness of the raform planning and explain why the national goals in the field of education can never be reached.

\section{Lack of Adequate Teacher Training:}

Secondary shool teachers are of two categor1es. Teachers in the firat cycle recelve two years of tratning at the Feculty of Pedagogy, while teachers in the second cycle recelve four years. They all are required to have the Beccalaureate II to quallfy for taking the entrance selective examination. BIther at the Paculty of Pedagogy of Salgon or Bue or Dalat are they trained to teach epecific subjecte: VLatnumees, English, French, History and Geography, Physics and Chemiatry, Mathematics, Civies and Philosophy. 11 The training program, designed and applied by profeseors who have recelved a French education, heavily caphesized the lecture method, 11teracy and theoretical content. Courees in profeselonal areas such as principles of learning, mathods of teaching, and tests and measurewents hare been overlooked.12 with such a tralning program, teachar-atudents would have no experience in leading group discuselon, encouraging intitative and creative thinking, or forging sclentiflc Judgwents in pupils. They were not accuetomed to supporting their works by 11 brary research

11 Kguyen-Duc-Kion, A Degign for the Evaluntion of student Progrese in VIetnemese Secondary School, unpublished doctoral disectetion (Sjrecued Unfversity 1969), 151.

${ }^{12}$ Ib1d. 
or other avallable 11terature. Moreover, they have no experience teaching in the claseroom during their performance in the Faculty of Pedagogy. However, they were aware of the1r future place in the social hlerarchy, ready to follow falthfully the curriculum as given and to tranomit to the young students what they thought necessary to master the content for exantnations.

With such profeestonal background and the traditionally misled concept of the "man of leieure," it would not be difficult to guese the poor quallty of Inetruction students recelved in secondary school. The earlous shortage of teachers at different levels, particularly at the eecondary level, cane to devaluate the effectivenese of training programs for high achool teachers. In the school year 1967$1968^{13}$, to meet the Increasing need of lower secondary teachers, the Mindetry had lowered the training perlod of two yeara to a rapld oneyear for holders of the Bacceluareate II. According to Nguyen-DucKen ${ }^{14}$ the majority of teachers in the lower grades of the firet cycle were recrulted among people who bad only the high ochool diploma and had no orlentation or teaching practice. F1gures in Table II 11lustrate the critical Increase of secondary school enrollment and the shortage of secondary teachers:

13"Republic of V1etnem: Bducational Developmente 1967-1968," International Yeaxbook of Educat1on., $\mathbf{0 x \times}$ (1968), 552.

14 Nguyen-Duc-K1en, p. 151. 
TABLE II

SECONDARY SCHOOL EMROLLMENT AND SECONDARY TEACHER TRAMING FROM 1965 TO 1968

\begin{tabular}{lllll}
\hline $\begin{array}{l}\text { SCEOOL- } \\
\text { YRAR }\end{array}$ & $\begin{array}{l}\text { SECONDARY } \\
\text { PUPILS } \\
\text { INCLUDIIG } \\
\text { PRIVATE }\end{array}$ & $\begin{array}{l}\text { TEACHERS } \\
\text { NEEDED (FOR } \\
\text { CLASS OF } \\
\text { 50) }\end{array}$ & $\begin{array}{l}\text { TEACHERS } \\
\text { IN PUBLIC } \\
\text { HIGH } \\
\text { SCBOOLS }\end{array}$ & $\begin{array}{l}\text { TEACHERS } \\
\text { TRAIMED }\end{array}$ \\
\hline $1965-1966$ & 370,660 & 7,413 & 1,829 & 300 \\
$1966-1967$ & 417,914 & 8,358 & 2,854 & 300 \\
$1967-1968$ & 470,925 & 9,418 & 3,232 & 425 \\
\hline
\end{tabular}

Sources: (1) Republic of Vletnam: Bducational Development during the school-years 1965-1966, 1966-1967, 1967-1968 publ1shed in Intermat1onal Year Book of Education, 1966, 1967, 1968.

(2) Report on Progress of Bducation in Vietnam during the school-years 1965-1966, 1966-1967, 1967-1968 at the Internationel Conferences on Public Educat1on, Geneva $1966,1967,1968$.

\section{Attitudes and Responeiblifty of Teachere Tourd Students:}

To compensate for the deficit of tenchere in secondary schools, the government Implicitly encouraged the expanation of private aecondary echools in apite of the Constitution which aseerts that basic education 1o compuleory and free of charge (article 10). The private hlgh school "Industry" has been developed to such a degree that the number of private secondary teachers is almost triple that of public eecondary teachers as shown in Chart I. Private institutions vhlch recrulted adventurow teachera at all levels from different sourcen, 
CHART I

GENERAL SECONDARY SCHOOL TEACHERS

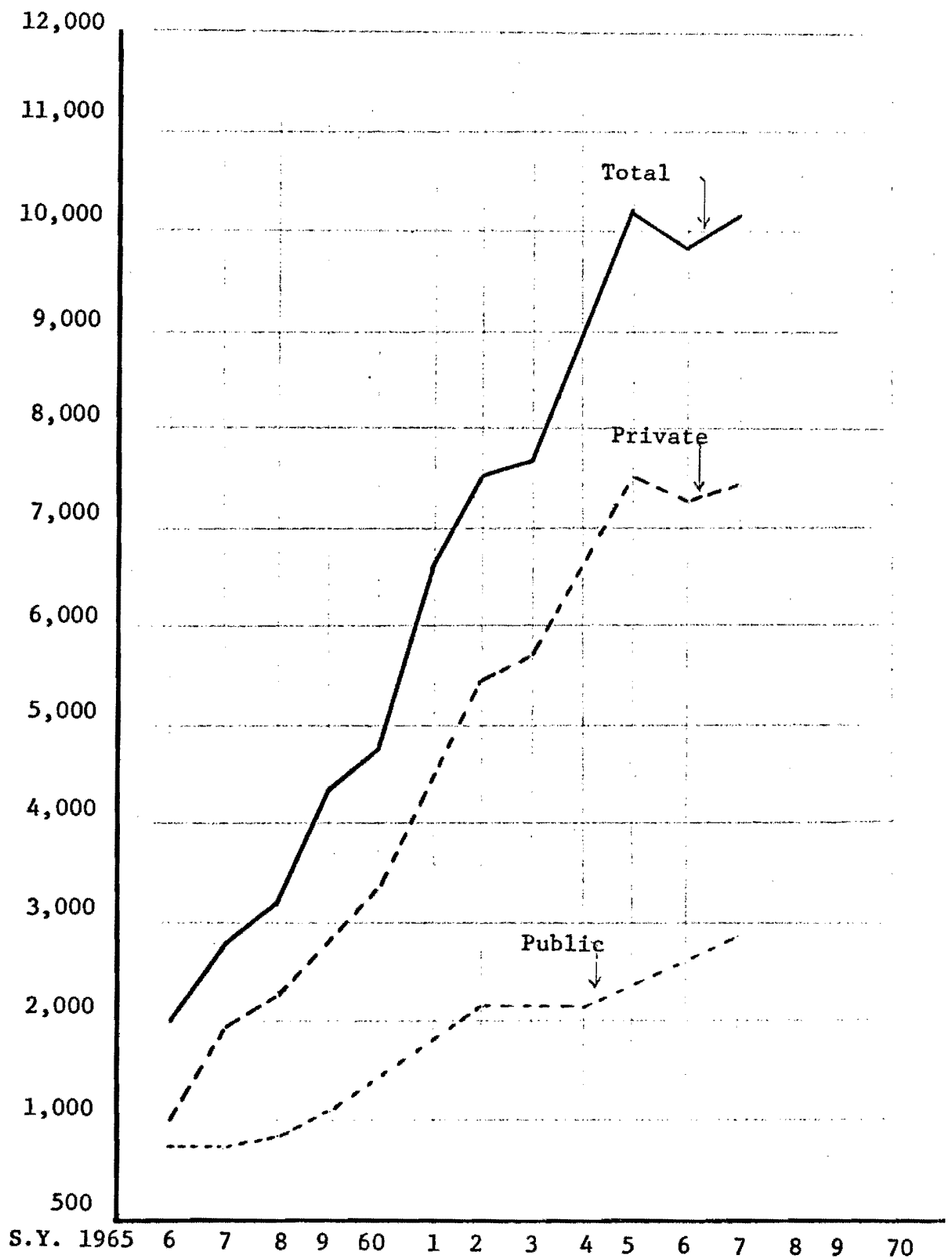

Source: Education Vietnam: Proposals for Reorganization, p. 263. 
even from public high schools, transformed the art of teaching into a diohonest comercial affair. Wthout any background in teaching tralning, private high school teachers provided a large percentage of education, usually of poor quallty, to the youngeters who falled at public h1gh school entrance exandnation. Regular curriculum was cut down to some main subjects required at the national examination. Ironlcally, private hIgh schools attracted public secondary teachere wth higher salaries and it was not unusual to see increased confidence In private education anong parents, because some public secondary teachers taught wore conscientiounly in private schools than in public schools.

Wth the Increneing devaluation of Vietnanes money and the mensce of Inflation, the etandard of living of lintted-salary employees such as teachers was not too desirable. Any aecondary teacher who needed to earn aome extra woney for his fandly had no way to accompliah this but by teaching in private schools. That explained why nost of them adopted an attitude more and wore negative with respect to the1r reaponatbility. They were unlikely to agree to teach wore than the number of hours a veak required by the kinietry of Bducation. Instead, they devoted more time to their private classes. Concerning themgelves with "extra-teaching," they neglected the1r own duty toward otudents in public schools. Wost of the time they lectured in classroom, somatimes without explanation. There was no free discuseion or conmunication between teachers and students. Wh regard to their students, they always observed a distance to maintaln their personal 
prentige and the apparent disclpline in the classroom.

The young teacher' Insecurity caused by the war made him deny his reoponsiblifty toward the etudents and try to escape from reallty by falling to Implement any good educational program. The perepective of a long military service and an endless war made them skeptical about the effectivenese of education and there was a growing tendency of pelcurien and extotentlallam anong young teachers. Sowe of them were not willing to serve as good models to the youngstere In many appects and by their private conduct of life were oubject to many critfelems by the etudents' perents.

II. THE NEED FOR A GUIDANCE PROGRAM

As consequence of the shortage of secondary teachers, the Inefflctency of these due to the poor quality of training as wall as to the Irresponelbility of the1r ettltude toward students, education provided at secondary level in public high schools did not respond to the set-up goals although tremendous efforts have been made by euccessive governmants of the Republic of V1etnam. For a country in which aconomic development depends mainly on eklilful labor, the resistance to change and 1 ts consequences as have been denonstrated would be a wase of manpower.

W1th the rep1d growth and development of the elenentary education, there has been a heavy preseure on the expanaton of secondary achoola. 
To the last statistice in $1969^{15}$, only 24 percent of the primary youth attended the secondery schools. This meant only 600,000 out of $2,600,000$ boys and girle between the ages of 12 and 18 were able to recelve a secondary education fron both public and private schools. If we look back to the year of 1959 where the enrollwent of eacondary schools was four times less with 120,000 we could say that 1 was a remarkable leep forward in educational development for a country bearIng the heavy charge of an endlese war.

\section{High Percentage of Drop-Outs:}

Onfortunately, examination of the pattern of all secondary achool dropoute as shown In Chart 2 would suggest a less optinfstic pleture. Back in $1962^{16}$, over 73,000 studente were earolled in grade seven (B1xth grade in the U.S.). In 1969, only 10,804 or 14 percent of 1962 enrollnent ware bucceseful in the termatnal year of Baccalaureate II.

One wight wonder what will happen to the 86 percent of the secondary scholar population who falled to secure a Baccalaureate II degree. And what jobs could be provided to them as unktilful as they were with a vague knowledge of verbal generelizations. But another crucial question could be rateed as to what reasong there could be for auch a fallure of education. Certalnily the answer would

15 Knox, Donald M., "The Case for Comprehenglve Bducation in V1etnan," a epeech delfvered at the Rotary International Club of Salgon on December 18, 1969, p. 10 (mimeographed).

16 Ib1d., p. 11 . 
CHART II

PATTERNS OF ALL SECONDARY SCHOOL DROPOUTS 1962-1969

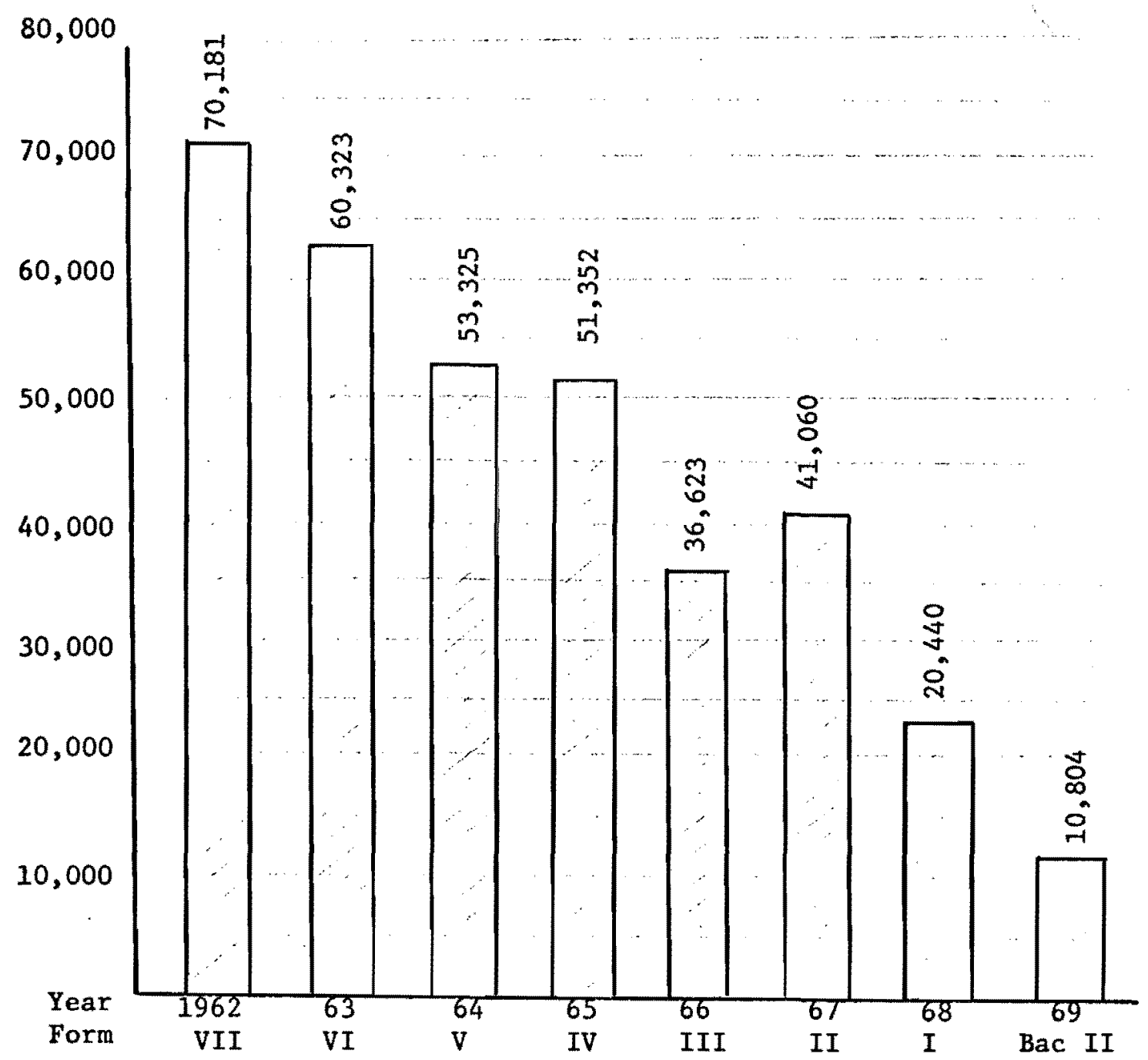

Source: Donald M. Knox, The Case for Comprehensive Education in Vietnam, 1969, p. 13. (mimeographed). 
have wany aspects, and one of these would fall into the scope of guldence in the secondary schools. It would be safe to state that if the V1etnamese high achool studente had been provided with orientation, advice, and help to make reasonable decisions in choosing the right fields of tudy to ovarcome their personal problem, the number of dropouts would be less. Any V1atnamese Intellectual who vas concerned with the reform of national education, would suggest that guidance and counseling could help improve the present altuation. Vu-Tam-Ich17 in his "A Historical Survey of Educational Developmente In V1etnam" wrote:

\footnotetext{
...the professtonal education of prospective teachers thould be broadened to Include courses in curriculum aching, echool adminiotration, as well as guidance and counseling. So far, these areas have been neglected in Vintnam, eince they have not been regarded as forming a part of the equipment of the classroom teacher. They are, hovever, very Important because they afford a basic understanding of activities which obviously affect teaching to a great extent.
}

Recently, in 1969, in his Ph.D., dissertation, Nguyen-DucKLen, a former V1etnamese h1gh school teacher asserted that:

${ }^{17}$ Vu-Tam-Ich, A Bletory Survey of Rducational Developmente in V1etnem, (University of Kentueky, Lexington: College of Bducation Decenber 1959), 130. 
The main emphasis of a school gutdance program 1s on the placement of studente in various courses in such a manner that fallure cen be reduced to a mintmum. Guldence also enables each student to understand his own abilities, interests, and personality trafte, and to ralate then to bis future 11fe plans and goals.18

BRIEP HISTORY OF GUIDANCE PROGRAM

If a guldance program to to be recomended by V1etnamese educators for the high school, a brief revien of 1ts history would be useful before undertaking any further discuselon on the application of such a program. In Vietnam.

Throughout human history, eome preliminary forms of guldance have been known. Clcero, in the firat century B.C., stated "we must declde what manner of men we wish to be and what calling in life we would follow."19 Locke wrote in 1695, "He therefore who is about ch1ldren should well study the1r Hatures and Aptitudes, and see, by often trials, what turn they ean1ly take."20 In the United States, a syetem of Mechanical Arts in San Franc1sco in 1895. About 1902, state-supported achools providing similar vocational training vere founded in Massachusetts and Wroconsin. But 1t was Frank Rarson

18 Nguren-Duc-Kien, p 189.

19 Henry B. McDante1, Guldance In the Modern School, (New York: The Dryden Press, 1956), p. 22.

20 rb1d. 
who first introduced the term of vocational guidance in 1908 when organizing at Boston the Vocational Bureau devoted to absiat young people to make vocational cholces based upon the1r aptitudes and Interests. 21

In 1909, through the efforts of the Vocational Buraau of Boston, one counselor-teacher was appointed for each elementary school and hlgh school in Boston. These teachers were not released from any of their teaching:duties to act as counselore and were not provided with funds for neceseary materials.

In 1911, Frank P. Goodwin organlzed a guidance program in the Cincinnatt1, Ohio schools which Included the following main points:22

1. Study of the Individual and the use of personal cards;

2. Collection of occupational Information, Including Information on the pereonal factors required for succese in different types of work;

3. Knowledge of opportunit1es for advanced training, speclally college training;

4. Better adaptation of school courses to the vocational needs of students.

In March, 1910, the flrst national conference on vocational gutdance, sponsored by the Boston Chamber of Commerce, was held and the National Vocational Guidance Assoclation of America was establiehed.

\footnotetext{
21 Ibld.

22 Ib1d.
} 
Successive national conferences took place In NeV York City In 1912, and in Grand Rap1ds, Michigan In 1913. 23

In February $1933^{24}$, the National Occupational Conference or N.O.C. was founded for the atudy of occupational-adjustment problems. Financed by the Carnegie Corporation, this organization published from 1933 to 1939 the perlodical "Occupations," Indexes of books and pamphlets and carried out many other projects of research rolating to the broad fleld of guldance. These actiditie made more people acqualnted with the new function of guidance and promoted the "vocatlonel guidance" movement.

During the expansion of the vocational education program, particular attention had been pald to eecondary education. In $1918^{25}$ a Cosmiseion on the Reorganization of Secondary Education was appointed by the National Education Aseociation of America. The report of this comission, known as the "seven Cardinal Principles of Education" contained recomandations for training of all pupile in the age range of 12 to 18 years. The goals of training suggested were:

1. Training in the malntenance of health.

2. Tratning in the fundamental process.

3. Trainlng in worthy howe membership.

4. Training in obtaining and maintaining a vocation.

23 Ib1d.

${ }^{24}$ Hutson, Percival W., The Guldance Runction In Educacion, (New York: Appleton-Century-Crofts, Inc., 1958), 7.

25 Hatch and StefElre, Adminiatration of Guidance Services, (Bnglewood Cliffs, New Jereey: Prentlce-Hall, Inc., 1965) 11. 
5. Training in clvic reaponsibilities.

6. Training in use of leloure time.

7. Tratning in the development of ethical character. 26

The evolution of Interest in guldance in education correeponded not only to the increased population of the United States and the development of the Industry, but also to the Increased complextty of social organization. According to Henry McDantel, 27 the starting changes In method of production that began with the Induatrial revolution have contributed to the alnost complate separation of home and Job. As father and wother were often outalde the how for work, reaponsibilities for rearing, protection and guldance of chlldren became charge for other social unfte. As the Influence of the ethical and traditional values of the church has become lese Important, the main reaponalbilities for the practical vocational guidance of young paople fell onto the echoole.

In VIetnam, vocational guldance wa Ignored unt11 June $1966^{28}$ when the Minfetry of Education endeavored to make use of educational and rocational guidance at all educational level particulariy in the comprehene1ve schools. A guldance course was expected to be offered at the three oxieting Faculties of Pedagogy of Salgon Hue, and Canthe for those who wanted to become guldance counselors.

26 Ib1d.

27 McDanse1, pp 26-27.

28"Republic of V1atnam: Rducational Development in 1965-1966," p 402. 
By 1968, vocational guidance centera using psychological methods and teete had been established by the Minietry of Labor and the Mntetry of National Dafenge. Some technical Institutes 29 have adopted testing methods in rocationsl guidance.

The concept of guldance and counseling was relatively new to V1etnamese education. With the introduction of comprahengive high schools-11 In 1969 and probably about 100 in the 1970-71 school year 30 -an urgent need to provide guidance to students in their selection of subjects of study has been a tremendous task for the Ministry of Education. A few years ago, an attempt was nade to reeerve one hour per veek in the regular curriculum for gutdance and counseling. Unfortunately, teacher-counselors, trained in scademic subjects, had 1ittle or no knowledge of the fleld. According to the report of Vietnamese Education Institute ${ }^{31}$, this program of one hour per week in the curriculum has largely falled because of the teachercounselor's misunderstanding and lack of trainting concerning the goals and wethods of guldance and counseling. The report sald:

29"Repub11c of V1etnan: Bducational Development in 19671968," Internationn1 Yearbook of Education, p 554.

30 Nguyen Van Thteu, p. 4.

31 Dembo, Myron, et a1. The Percholostcal Foundatione of Teacher Education in Vietnam. (Univeraity of Southern Callfornin: Center for Internetional Education, School of Educstion, August 1969) p 36. 
The hour conbequently degenerated into an additional partod in which teachere would tench aubject matter when behind in their instruction, ox would complete their clerical work. At times the hour was used for a general "gripe eeselon," where etudents complained about other teachere, the curriculum, and thatr clasemates. 32

INCREASED NEED FOR BETTER ACHIEVBMENT IN HIGH SCHOOL

Wth the trend of education which demands better achievement In secondary schools, the role of guldance becomes a neceselty. The rapid growth of the Vletnamese secondary achool population (aee Charts III and IV) have reached auch a point that to provide Imediate equal aducationnl opportunity for every pupll would be difficult. A poet war pertod of soclal reorgentzation and changes vould come. These changes are upon the Vietnamese population and present to the V1etnawese high school students meny problews related to their performance and permonal adjustment. The change from an agricultural econouy to an Industrial economy, the change from a few occupation in government, offices and agencles to thounands of apeclalized jobs, the change from a traditlonal concept of academic and theoretical education to a scientific and practical one, need adequate preparation on the part of high achool for a fruttful 11fe In the decedes Imediataly ahead. Th1s would Imply the noed for guidance services that are directed to helping the individual V1etnamege pupil to assese himeelf and to plan reallatically for tomorrow. 
CHART III

RATE OF INCREASE IN SCHOOL POPULATION

FROM 1961-1962 TO 1965-1966

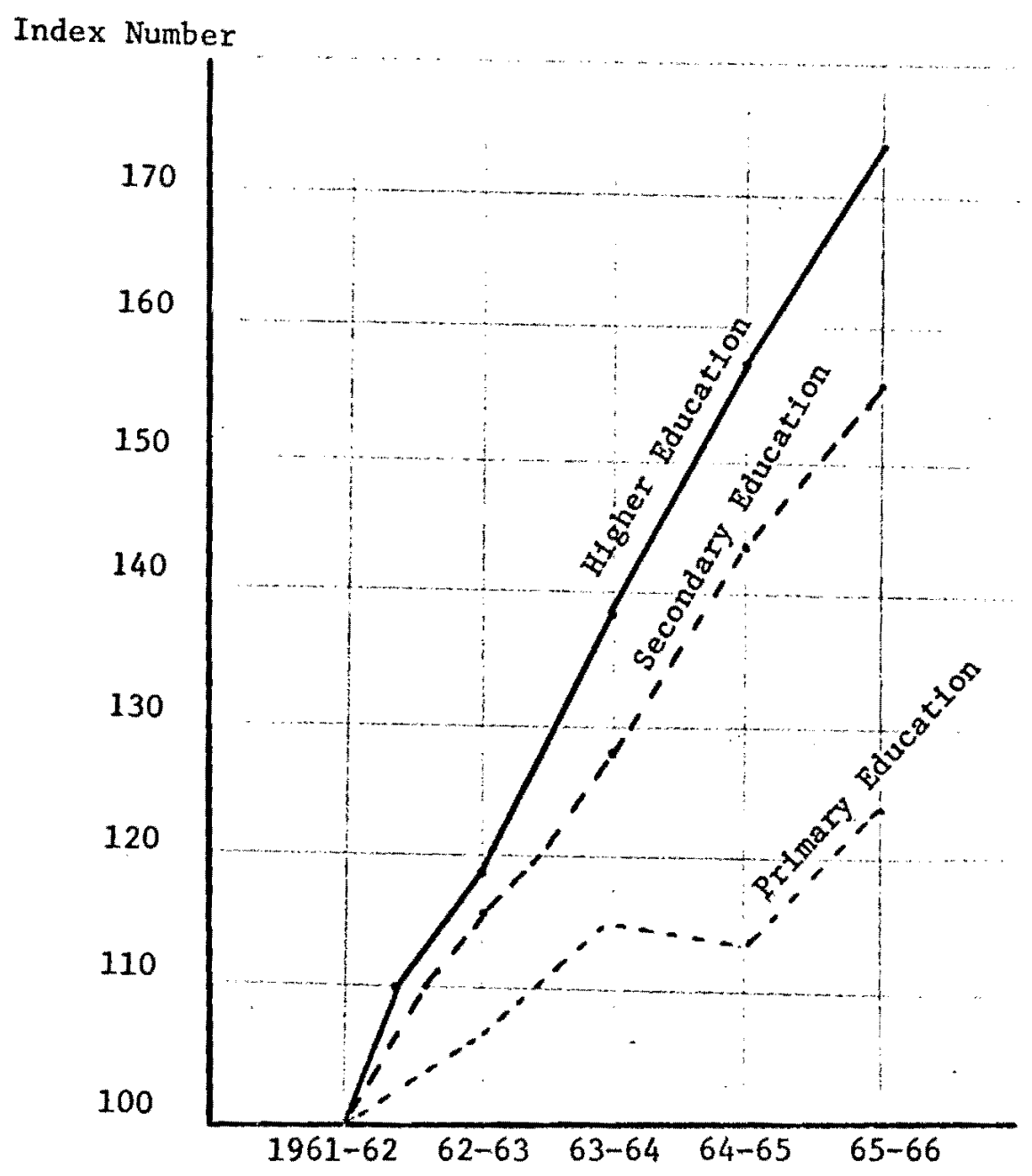

Source: Report on the Progress of Education in Vietnam during the School-Year 1965-1966 at the XXIXth. International Conference on Public Education, Geneva, July 1966. 
CHART IV

SCHOOL ENROLLMENT COMPARED WITH TOTAL AGE POPULATION IN $1965-1966$

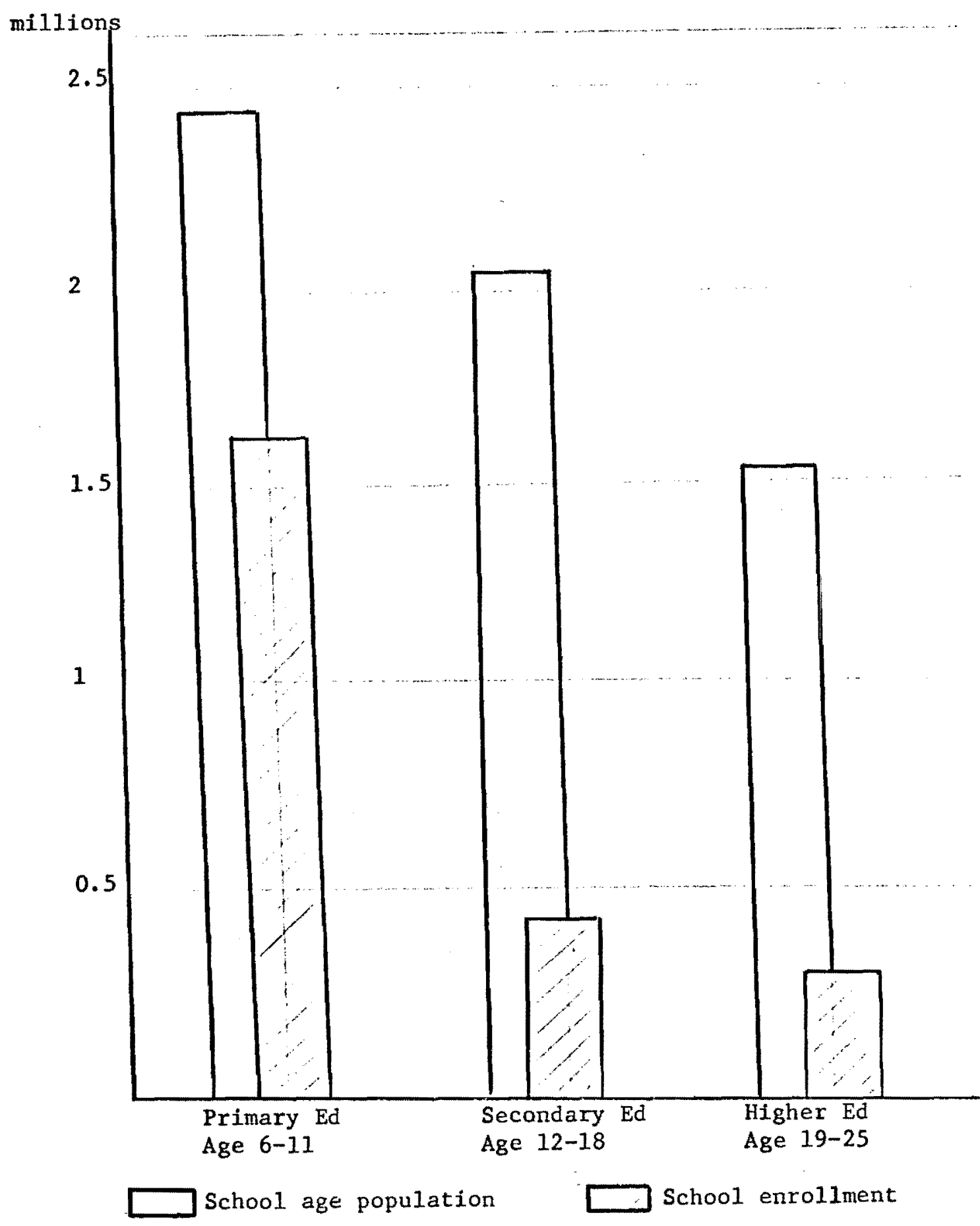

Source: Report on the Progress of Education in Vietnam during the School-Year 1965-1966 at the XXIXth International Conference on Public Education, Geneva, July 1966. 


\section{A PROPOSED GUIDANCE PROGRAM POR VIETNAMESE HIGH SCHOOLS}

\section{GENERAL OBJECTIVES BASED UPON BASIC PRINCIPLES OF GUIDANCE, NATIONAL CULTURE AND TRADITION, AND GOAL OP RATIONAL EDUCATION}

The above analyale of the education aystam in Vietnamese secondary gchools relevant to the problem of guidance would lead to - tentative colution, a proposed guidance program for v1etnamese secondary schoole. The takk would demand a great effort in seeking reallzable objectives for a country which bas been in a process of rap1d development. The reader should not forget that Vietnamese education in many aopects, has no resemblance to that of the United states. What succeeds in the fleld of guldance in the Undted States could not be fruitful in Vietnam if differentiation in culture, tradition and national goals vere not taken into account while establiehing general objectivee.

At the writing of this easay, guldance programs in V1etnamese secondary schools have been in a state of experimentation and there hae been no lagal basis for guidance in publie high schools. However, In the present Thu Duc Demonstration School in Vletnan, guidance has 
baen introduced since $1965^{1}$. It 1s proposed that in order to contribute to the development of guldance in Vletnamese secondary achoole, the following objectiven might be useful:

1. the guldance program should center on the studente' needs. Studente' personallty should be respected.

2. the guidance program should provide studente with facilities and opportunities to underatand themelves and to solve their own problems.

3. the guldance program should encourage and austain a democratic relationship between tachers and students.

4. the guidance program ahould provide teachers with Information on the students' problem to be able to underetand and to deal with them.

5. the guldence program should provide students up-to-date Information on vocational ehoicas or higher education and aselst them in making plans and decisions.

6. the gutdance program should help the parents to underatand more about thair children's problens and to support guidence setivities at school.

7. the guldance program ahould emphasise the ethical traditions and halp reduce delinquency and mental health.

8. the role of the teacher in classroom should be redefined to deal with the guidence program.

1 Raines, B111, "The Development of Guldance and Counseling Prograns In Vietnamese HIgh Schoole," mimeographed, p. 1. 
9. the teachers in secondary school. should be aware of the Individual differences of students.

10. the Interaction between teachers and students should be encouraged to promote students' self-confidence, motivation and sense of value in learning and evaluation of their performance.

These suggested objectives should not be considered as apart from the V1etnamese social Iffe, but should deal with the national goals. The concept of guldance 18 so broad that education and guldance would be almost synonymous. Then the objectives of guldance must be broad enough to serve national objectives of education. A statement by Miller would 111 ustrate this broed concept:

Guidance Includes the sum total of efforta and Influences of those who asist an Individual, through aseociation, counsel, diseenination of facts, exployment of approprlate speclal techniques and control enviroument, to reach h1s optimm personal, soclal, vocational, cultural, and spiritual development. 2

Thus, to establiah objectives for guldance would seem 11kely to astablieh objectives for all of education, if not for most of living. The preceding objective in Vletnamese secondary schools then should be concerned with all phasea of national education.

So, the following basic princlples should be considered while eatabliahing a guidance program:

1. the reason for the guldance program must be understood in the communtty as well as in the school.

2M11ler, Carrol H., Foundation of Guldance, (New York: Harper and Brothers, 1961) 401-402. 
2. the entire staff of the school must be lavolved in the program.

3. the program must be besed on the reality of the comonity' 11fe.

4. the guldance progran must be a continuous atage of eoctel evolution. 3

The firat principle relles on the fact that the traditional gep between school and comwuntty has long been the maln obstacle to any butual compreheneion among parente, teachers and otudents. On one alde, parents, wost of them laborers or farmers, have no time to take care of their children's educetion. Most are not likely to be wiling to participate in school activitied or to learn what their chlldren are dolng in the claseroom every day. Rare are those parento who reapond to a PTA Invitation for meeting or School Day. Many of them return the school bulletin without algaing it as they are asked to do. Education, they eay, Is an affair of teachers and school. Nonetheless, they ceem to be Interested in what teachers recomend that they do for the benefit of their chlldren's performance. On the other alde, school reaponibility in VIetnam is misunderstood by large numbers of teachers. These tenchere conalder themselves as raeponalble only for what is relevant to teaching in the claseroom, expressiy to routine curriculum fulfiliment. Vialts to parente, although mentloned and encouraged in the official echool

IArbruckll, Dugald s., Guldance and Counseling in the Classroom, (Boston: Allyn and Bacon, Inc., 1961) 373-374. 
policy are never carried out. The high cost of living, the repercussion of the war over meny aspects of 1ife including the draft for miltary service and the shortage of taachers have been good excues for fallure to meet parents. Consequently teachers are un11kely to be ware of the students permonal problems at home. The aecond principle is based on the necessity for teachars to understand their nev role in the clesgroom and to cooperate in any guldance activity as Johnston, Peters and Evraffe stated that "every teacher is a gutdence worker." In recent years, parento complained about school faflures and wanted thelr ch1ldren to succeed. Most of their criticlem centered around the curriculum, methode of teaching and teacher preparation. Generally, people Ignored the new concept of aducetion and the function of guldance service in school. Education mant to them the retention of the large amounts of knowledge required to pase exnmination. Today, wth the new trend of education, public sehools ohould be for the children's benef1t. If the educational program is to be best adapted to them, then the guldance ph1losophy among all staff members of the school 1s necessary. The staff mant be Involved in the gutdance progran to make it successful.

The third principle assumes that not only should the guldance program be understood by the community but it should focue more on the reality of the commity's 11fe. One is to be reminded that the matn

${ }^{4}$ Bdgar G. Johnston, Mildred Peters, and W1111an Evraiff, The nole of Teacher th Guldance, (Bnglewood Cliffs, New Jersey: Prentice Bal1, Inc., 1959), 6 . 
activities in a Vletnamese community, whether it be a village or a district, have long been a smulated denocracy. In fact, through many centuries, the vietnamese people, used to belng treated dictatorially by feudal landlords and v1llage authorities, have been unable to take any inttlative in promoting the progress and welfare of their own community. Traditional customs, anchored in their mind from generation to generation dictate a passive attitude to any plan or program set up by the government.

Thus the guldance program should not be aloft in the unrealistic atmosphere of optimism based on apeculating eupport of the local PTA. Most parents in small town are unlikely to have had sufficient education to be interested in the program and have been unable to cooperate effectively with school.

In Salgon, where most perents have an easy life, the guidance program could be partly successful. In low soclo-economic areas, such as provinces in the centzal area of Vietnam, the majority of parents are farmers and can hardly provide chlldren with facllities for learning. They ignore or deny their children's problems if told of them, and quite often have deeprooted prejudices against the value of education. Having worked hard in the rice flelds for their whole 11ves, they seem to wish their children success in administrative careers rather than in agriculture, husbandry or business. Such attitude would hamper the vocational guldance program and Impede the training of techniclens necessary to set up a self-dependent economic structure 1ike those in South Korea or Pormosa. Therefore, the 
guldance program in high school should be adapted to each spectfic area with 1ts maln differences in traditions and activities. Teachercounselors would do better to confront the parenta, to discuss, and to help them understand what their ch1ldren really need to be successful rather than to send home forms and reports to be filled out. The fourth principle 1mplies that the guddence process should not be undertaken only at some spectal phase of the academic period but should be carried out at all levels and at the entrance to the h1gh school as well as after graduation. In short, the guldance program should be a continuous process through the seven years of secondary education. The young Vletnamese high school student needs to be orlented at the sixth grade to be fandliar with the quite different subjects and learning procedures and with tean teaching. Th1s phase is the most 1mportant. He needs to be guided at the ninth grade to choose one of the four branches offered in sentor program. At twelfth grade level, he needs to be oriented toward higher education or vocational facilities. In addition, throughout the secondary academic years, he should be assisted at each grade level to overcom any personal problems he encounters for promotion to h1s next step.

\section{PROCEDURES}

\section{ORGANIZATION OF BASIC GUIDANCE SERVICES}

If guldance has frequently been defined an the "process of assioting Individuals to 1mprove theix adjustment, ${ }^{15}$ then, it may be

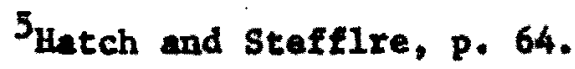


sald that guidance services are organized primarily for the purpose of helping the stuient to attain his maximum potential of development and adjustment. With the above principles as guidlines and in order to fulfill the selected objectives, the guldance program is set to be served in any given district or province high school. But at the present time, guidance services have been completely fore1gn to most of the V1etnanese traditional high 8 chools even to the newly born comprehensive high schools.

It would be unrealiatic to plan en organization beyond staff abllities of the school with complete guldance function services such as seen in any Awerlcan standard high achool. On the contrary, guldance services, should be 1 imtted to the very beginning phase of guidance development and flexible enough to serve in a soclety in constant change. However, guidance services, to be really effective In the future, must not be limited to some basic functions almed to satiafy a short-range program dictated by a shortage of qualiffed guldance personnel. To establiah a basic foundation for the prospective guldance in VIetnamese secondery schools, the following gervices are to be suggested:

1. Counseling. Counseling 1s the most Important service of the guldance program. Early in the development of the professional field of guldance, the term "counseling" was used as synonywous with "guidance." Counseling has now com to mean "that part of guidance program thet ealots an Individual to self-underetanding and, through this, to a self-realization and acceptance of his social responal- 
bility." $" 6$ The primary technique of counseling is the interview, the face-to-face relationship between the counselor and counselee. According to Patterson ${ }^{7}$ counseling is a professionsl relationshtp, established voluntarily by an Individual who feels the need of paychological help, with a person trained to provide that help. By Interviewing individual students, the counselor's primary function 1s to assiat students in educational and vocational plonning as well as in personal-emotional problems. "Bvery student should have the benefit of Individual Intervlews in which specific steps can be taken to assist hin in the solution of his problens as they ar1se."8 The relationship between counselor and student should be based on an attitude of mutual respect and confidence. The counselor should gat rld of h1s own need for the traditionsl self-esteen in order to accept the client as a worthy person and to create an atmoephere of frankness and honesty, and total absence of threat in the interviews. His function requires a deep knowledge of human relationships and of speclal techniqued of interviewing. It also requires a firm commtment to maintaining the confidentiality of what the sudent revenls to hiv during the counseling intervitew,

6Ib1d., p. 178.

7Patterson, C.H., Counseling and Guldance in Schools, (NEw York: Herper \& Brothera, 1962), 112.

8 Dean C. Andrew and Roy DeVer1 W11ey. Administration and Organtration of the Guldance Progran, (New Torkt Harper Brothers, $1958) .25$. 
2. Appralsal. The purpose of thls service ts to collect and to organize Information regarding pupils that teating alone is unable to provide. The testing program repreeenta only a part of the total effort to help the Individual because "the purpose of testing, ...1s to understand the Individual and to help him if need be, not to 'lay bare his psyche'."9 Tasts results, although algnificant, must be Included in a continuous and systematic progran of appraisal. Techniques presently employed in the appralsal of Individuals are based on accuracy of measurement and objectivity of reporting.

The information concerning a student, if complete and accurate, could help counselore, teachers and parents to predict his future behavior and achleverent. The record of each pup11, to be complete, should include the data about Identification, hota-commintty, health and physical growth, school history, abllity, aptitudes, achievenent, Interests and personal1ty. 10

The procedures most frequently used to gather data on the student are Interviews, questionnalres, health records, observation and report, autoblography, soclometry, dally schedules, diaries and 11feopace ourvegs. ${ }^{11}$ To understand a child we cannot rely only on the psychological teats he took in school. The testing program was dealgned to supplement the school records and the counselor's Impreasion of the atudent's Intelligence and ability to plan. "Pay-

9onald G. Mortensen and Allen M. Schmuller, Guldance in Today's Sehoole, (New York: John W1ley and Sons, Inc., 1960), 165. 10 Ib1d., p. 203. 11 Ib1d. 
chological teste are valuable instrumente in ald of the counselor, but cannot In themselves determtne a plan."12 So, the enormoul teak of gathering data about each student requires team work among teachers, adminiatrators, guldance workers, and even parente and studenta themse1ves.

3. Orientation. This service is to help each atudent feel at home in a new surrounding or activity by helping him to understand the traditlons, rules, and offerings of the sehool. Toure of the ochool, student handbook, and assemblies are devices used to orlent new pupile. The orientation progran should be undertaken at the beginning of the sxth grade and at the and of the 9 th grade before starting the senior sequence. Orientation to the academic program should also be provided for etudents moving up into new class. Every school should help new pup1ls get startad. There is more to this than helping the pup11 decide which aubjects to take. As Barbara Wright wrote:

Whether pup1ls are entering a consolidated high school from small xural schools, transferring to a sentor high school from a nearby funior h1gh school, or entering high ochool from elementary schoole in the same community, it is a tremendously 1mportant, and often a tarrifylng experience. They are likely to feel strange and quite loat in their new surroundInge. They are unecqualnted with the routines of the school; the bullding 1teelf 1a new; the teachers are etrangere; and moving from clase to clase is a new expertence... Often they are ase1gned to groupe in wich they have no friends...13

12Ernest harwa and Paul Schretber, Handbook of Counceling Techn1ques, (New Jork: The Mack11lan Company, 1963), 239.

13B. H. Wr ght, Pract1cal Handbook for Group Guldance, (Ch1cago: Science Research Aseociates, Inc., 1948), 73. 
A successful orlentation program prevents maladjustment by providing help with minor problem before they become major ones.

Possible activities to be included in orlentation program are visite to sending and recelving schools, exploratory activities, diseemination of educational occupational information, scholarship opportunities, military obligatione and employment. The Juntor school my hold an open house for pupils from elementary achools, or the high school may provide a college day, when college representatives are invited to school. The employment service may come in and register all senfors and others who are intarested in employment. The purpose of these activities is "to provide a continuous flow of Information about pupils and to bridge the emotional gap for pup1ls, so that he has some knowledge about his next step." 14

4. Placement. The placement service is broader than occupational pacament. According to Clifford P. Froehlich the service of placement "helps pup1ls gain admittance to appropriate educational facilities, whether 1t be a bigh school chemistry class, a college, an apprenticeshtp, or a trade school. In essence it helpe them make use of their opportunit1es."15 A school's guldance program mat be concerned with the success 1 ts graduater have in finding jobs. The placement process must begin early during the first sentor year and should assist the student in selecting the school, or college best suited to his neede and to the training he

${ }^{14} \mathrm{Cl1ff}$ ord P. Froehlich, Guidance Services in schoola, (New Tork: McGraw-H111 Book Company, Inc., 1958) 15.

15 Ib1d., p. 231. 
has received in high school. The placement process also takes into consideration the ablilties, the pereonality, and the preparation of the etudent.

The job placement or vocational plecement 18 another businees of the school which must pay attention to the job obtained by greduates, by those dropping out of achool and those who work part c1me. It 1s then necessery that the echool develops a close working relationship with the local office of Employment or Labor, as well a the univerulties in the country. School racords including attendance and health records, should be fully utilised in placement of etudente.

5. Follow-up. The follow-up cervice is another important school-cowauntty function of guidance. "The follow-up is tact recognition of the fact that guldance is a continuous process."16 Iollow-up refers to number of purposes and procedures by which continuous information can be gathered and analyzed to determine development, activit1es, and adjustment of students. Easentially, a follow-up of students can be used to revise the curriculum, to Identify students In need of asistance; and to Improve the guidance program. 17 A functional follow-up program ahould be concerned with those students who leave before they are graduated (drop-outs) as well as those who have completed their schooling. Information gathered in a follow-up etudy depends upon the graduates or drop-outs

16 Mortensen and Schmuller, p. 389.

17 Andrew and w111ey, p. 294. 
In quastion, their familes, frlends, teachere, and employera, A follom-up study serves to analyze the success of vocational education In terms of fitnes for job, length of etay, etc. Results of the follow-up program are of value not only in terms of halping the graduated or drop-outs but also in clarifying the preaent objectives. The adminietration of guldance services in Vletnan have not been a problea elnce the guldance program in high echool is an experimental atate. For years, there will not be more than two councelors in each bigh school. The princlpal wil be directly reaponetble for carrying out the gidance program of the school. But once guldence develope throughout Vietnamese high schools, the adalnietration of guidence vil demand competent adminietrators who must understand and support the program. The administrators must respect the profeselonally trained counselore and have confidence in their work.

The critical lack of qualifled guldance paraonnel in the initial phase of guidance in V1etnam has been pointed out by B111 Raines 18 , "...the second major problem 1s the lack of qualifled guidence epecialiate..." As a guidance advisor responelble for pronoting guldance in Vietnam, he has suggested a training program to produce teacher-counselor for the flrst hundred comprahensive b1gh schools. According to Dr. Raines, the Immediate objective should be to offer a special one-year in-service training course for high school

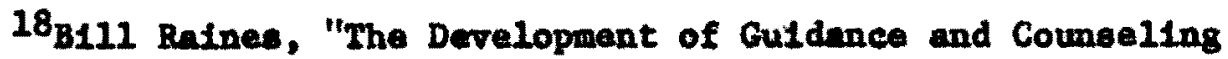
Program in V1etmamee Bigh 8chools", mimeographed, p. 3. 
teachers. These candidatea, chooen from the regular teachere, w111 assume the function of teacher-counselore after the training and are the first ploneers in the fleld of guidance. They w11l be ateigned no more than elght hours of academic tesching, and less if posalble, and work as counselore at least one half of their time, 19

An In-eervice program has also been proposed for all teachers In the school in order to understand the objectives of guldance and to support guldance activities. In the near future, all prospective junior and sentor school taachers should be required to take one course In "Principles of Gutdance."

The anjor areas included in the curriculum of the proposed oneyear training couree are: 20

1. OrIentation to guldance.

2. OrIentation eervices for entering etudents.

3. Assistance for students having academic difficulty.

4. Aastetance for pup1le having behavior and adjustment problems.

5. Appratsal services, extra-curricular activities and cumulative records,

6. Planning servicas for pup1ls.

7. Individual conferences wh studenta and parents.

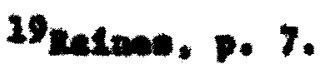

20 rat. in 22-13. 
III. EVALUATION OF THE PROGRAM

S1gnificant reoults at the Thu Duc Demonstration School.

Although introduced into VIetnam only since 1959 by V1etnamese aducators and American advisors, the concept of guldance has yet matertalized only in 1965 at the Thu Due Demonstration High School. 21 Constructed In 1964 on a large axea of 5.107 oq. m., the bullding wee the flret high school In Vietnam which had all the equipment and factlities of a modern high school currently eeen in any modern country. Wth the cooperation of a tean of OhIo UnIversity Education advieore, a new curriculum was dasigned to renlize the new concept of education:

It shall be the phllosophy of the Thu Duc Denonstration h1gh echool to provide a secondery education for all its etudents consistent with their Individual interests and abilities wo that they can rightfully asame their roles as contributing members in a fzee, democratic V1etnamase cociety. 22

The first cycle curriculum provides students in four years with the basic elements of secondary education. The rigid program of the first two years serves as observation etage and pre-orlentation. The followlng two year progran, more flexible, orlents atudente to the selection of elective courees in the second-cycle curriculum which covers 3 years. Four new courses of study are wallable: industerial arts, businesa education, home economfes, and agriculture.

${ }^{21}$ B111 Raines, p. 1.

22 Thu Due Demonstration Secondery Sehool, Feculty of Pedagogy Untvareity of Salgon, mimeographed, p. 1. 
Ben1des subjects in the areas of the practical arts, the curriculum also offers an excellent academic program for those atudents who wish to pursue higher education.

An experimentel program of guidance and counseling has been established to provide professional and vocational oriantation. A Guldance Committee ${ }^{23}$ carries out a guldance function to assist otudenta wh personal and acadentc problews. The position of the Gutdance Council is bhown in Chart V. Wthin a short time of three yeara and with only one coumselor for nearly a thousand counselees guidance activitles have been developing in many aspects and according to Dr. Ralnes 24 sone services have been succeseful such as:

1. Ortentation services for Incoming 6th gradere. This program has been set up for 2 days prior to the school year and Involva the students, parente and teachers.

2. Educational guidance for studente in the 9 th srade. The last year of junior high school to very Important In the cholce of major field of study so a group guidence course 1s required of all 9 th gradere for one semester.

23 Ibld.

24 B111 Rainea, p. 7. 
CHART V

ORGANIZATION OE THE THU DUC DEMONSTRATION SCHOOL

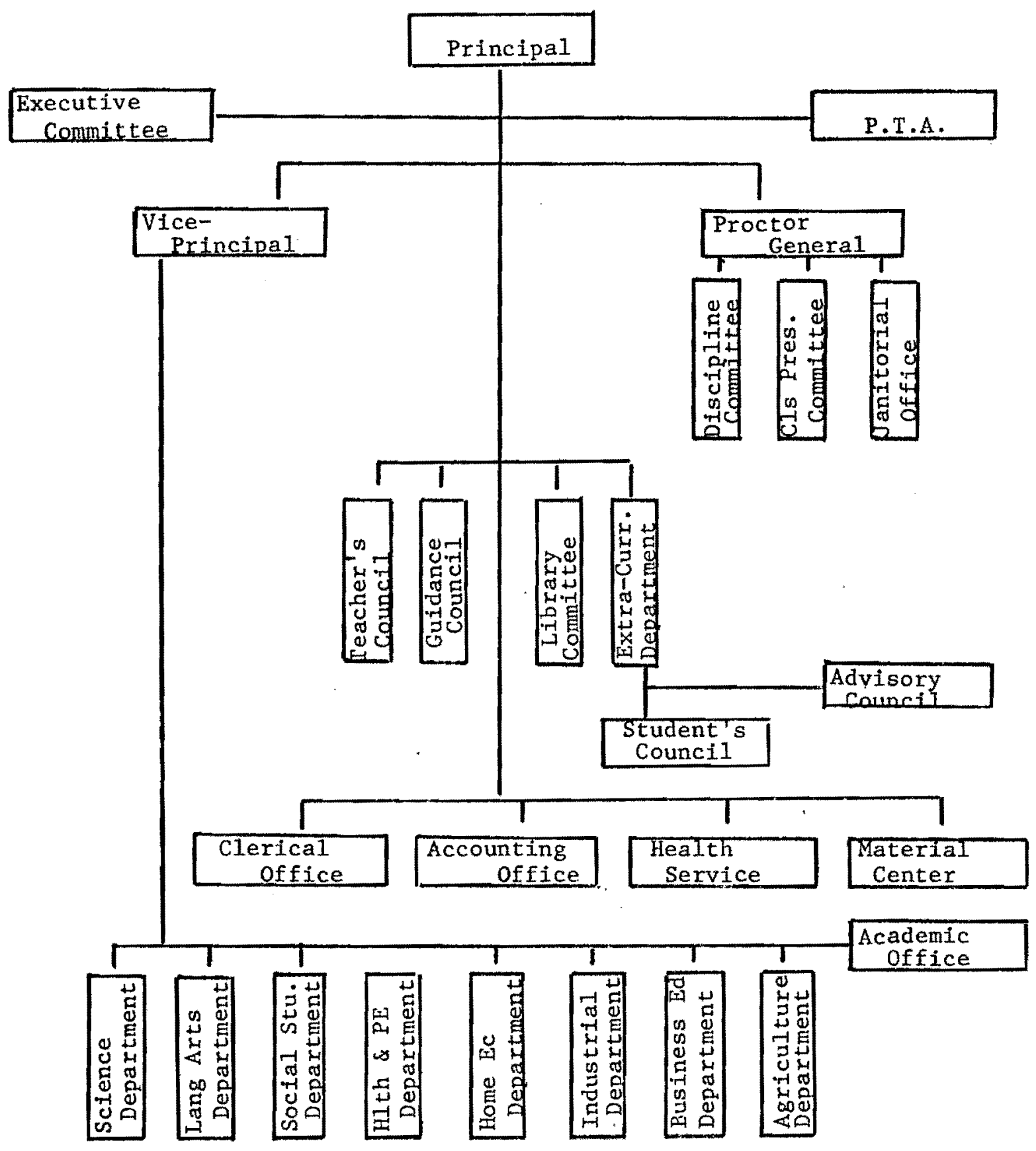

Source: The Thu Duc Demonstration Schoo1, Faculty of Pedagogy, University of Saigon, mimeographed, p. 4. 
3. Moral guldance and character development.

Each student in funtor high school has a group gutdance clase for one hour per week. Each year of the funtor high focuses on a different appect of the "Moral guldance" curr1culum; in the 6 th grade--school adjustment; 7 th grade-fantly adjustment; 8th grade--social adjustment; ninth grade--c1tizenahip.

4. Individual counseling services. The young students, who are now accustomed to be "selfreferred," have been seeking help from the guldance office.

5. Group counseling.

Group coumaeling has been used with students who are experiencing academic fallure. In one year, 43 studente who were on academic probation were back on regular status after partictpating in a progran of group and individual counseling once a weak throughout the year. Tables III and IV give more detalls on the improvement.

6. Service to parente.

Once aware of the beneficial activitios of this service, increasing number of parents have come to consult the counselor.

\section{Pointe of Views.}

It 1 s st111 too early to determine that the guidance program at Thu Duc Demonstration School has been completely succeseful. 
TABLE III

IMPROVEAENT OF 43 STUDENTS IN AN EXPERIMENTAL GUIDANCE PROGRAY

\begin{tabular}{lcc} 
& \multicolumn{2}{c}{ PERCENTAGE } \\
GRADE & $1966-1967$ & $1967-1968$ \\
\hline B- & $0 \%$ & $51 \%$ \\
C or higher & 237 & $100 \%$ \\
D or higher & $32 \%$ & $0 \%$ \\
\hline
\end{tabular}

Source: A Follow-up Report on the Probationary student at the Thu Duc Demonatration School, Faculty of Padagogy, University of Salgon, mimeographed. 
TABLE IV

BOLLOW-UP ON EICHT INDIVIDUAL STUDENTS WHO FAILED

FOUR OR MORE SUBJECTS

\begin{tabular}{cccc}
\hline & $\begin{array}{l}\text { SUBJECTS } \\
\text { FAILED IN } \\
1966-1967\end{array}$ & $\begin{array}{l}\text { SUBJECTS } \\
\text { FAILED IN } \\
1967-1968\end{array}$ & GRADE \\
\hline 1 & 6 & 0 & W1th a C- average \\
2 & 5 & 2 & With a B- average \\
3 & 4 & 0 & With a C+ average \\
3 & 4 & 0 & \\
5 & 4 & 1 & \\
6 & 4 & 1 & With a C- average \\
8 & 4 & 0 & \\
\hline
\end{tabular}

Source: A Pollow-up Report on the Probationary student at the Thu Duc Demonstration School, Faculty of Pedagogy, University of saigon, wimeographed

However, significant progresa has been made and certalnly the development of guldance in Vietnamese high school depends largely on how the guldance functions are carrled out in pllot comprehensive high schools and how effective they are.

So far the Thu Duc Demonstration School has been taking advantage of the large middle class population who are really concerned wth the success of their children. No major problems such as poverty, 
Ignorance and prejudices on the part of the parents arise.

A closer look Into the results brought about by three years of experience at this school would lead to the following points of ทew:

1. It is doubtful that the main objectives have been reached. In fact, with only one counselor who at the same time fulfilled the responstbility of principal and counselor and taught at the Faculty of Pedagogy, 11ttle has been done to Implewent the program of guldance. Dr. Raines himself was wondering if the few accompliabmenta In guidance at Thu Duc school could be sald to be successful. 25 The Group guldance course established for fourth form atudents was without lesson plans and Instructional materials, and was threatened to be cut down for lack of a teacher. The Moral guldance course hae been Introduced into forms in the First Cycle but covered the same content for bur years consecutively and a a result "seems very repetitious and difficult to justify."26

It appears that there has been no sequent1al progression in application of the program and each guldance function has been only partially realized thus falling to maximize the benefits to the studente. There was no atatistical figures that could demonstrate the auccess of some servicas. 27 such as orlantation services, educational and moral guldance, Individual and group counseling and

25 Oh1o Unlverafty Contract USAID/Educetion Semt-Annual Report, (January lat to June 30, 1969) 120.

26 Ib1d.

27 B111 Ratnes, p. 1. 
services, to parents. The only figure given in the probationary system concerned with the aforesald Improvement was of 43 studente. But this result might not be due to the application of the group counseling but to the change of attitude of teachers who were Influenced by pressure of the counselor, as has happened In American schools where atudents see counselors often as "buffers" between then and the teachers. ${ }^{28}$

2. It was too early to promote guldance programs in other P1lot Schools while at Thu Duc School the guidance function has been In 1te "trial-and-errors" stage. More time and ataff would be needed to accomplish all appects of the program.

3. No report of progress has been made in the fleld of testing about providing teachers and parents wh information on atudents' Intelligence, ab1l1ty, achlevement and emotional problems. Thls is Important, because V1etnamese atudents have never been subjected to ouch procedures. Teachers judgment needs to be based on data obtalned by selentific measurewent rather than on examination scores or on vague Information given by students who are not used to report personal problems.

4. The reaction of teachers and the principal to the role of the counselor in school hes not been taken Into account. The principal who bears the responsibility of the school administration and who recelved no troining in counseling would be 11kely to consider the

28 Hugh Lytton, "School Coumselor-An Outalde V1ew," Pereonnel And Guldance Journal, xxorvil (Septenbex 68) 15. 
counselor as his administrative assistant handing infractions of school rules rather than as an advocate for students. Teachers might regard the coumselor simply as another $k 1$ d of teacher created by the emergence of an "Americanized" soclety. 29

5. The counselor's personality has not been mentioned in the cholce of candidates to follow a special in-service training course. "Counselors are adjured to be honest and responsible and to strive for the highest professional standards." 30 The Vletnamese high school principal seens to 1gnore the importance of this new function and is I1kely to chose the docile teachers who would not contradict him after tralning, or he may have the Eendency to choose the ones whom he considere as undesirable or Incapable. This would affect greatly the functioning of the guldance program of the school.

It was not the intention of the writer to criticize a newly Imported role of guldance in V1etnamese high school but to contribute different points of judgment to help bulld a solld guidance program in the future.

In the circumstances of a socelty in culture expansion, certainly guldance deserves a high consideration in the aducational eystam of VIetnam, particularly at the basic level of comprehensive high school. For the purpose of better ut1lization of manpower, most teachers, principals, students and parents should be in favor of the guidance

29 Oh10 Report, p. 129.

30 Joseph Stubbins, "The Politics of Counseling," Personnel and Gutdance Journal, xocovil1 (Apr11 1970) 611. 
program. Counseling on educstional and vocational problems in the future would help avold waste of time and money in blindly speculative education. Vietnamese high schools should profit from the tremendous amount of experimentation in American schools when trying to fill the gap in education between the two countries. However, difference In culture, social relationship and economics should be carefully consldered before undertaking any leap forward. 


\section{CHAPTER $\nabla$}

\section{RECOZMENDATION FOR IMPLEMENTATION OR PROPOSAL}

At the time the writer is jotting down these 11nes, V1etnam is knowing the most traglcal hours of 1ta history. Caught in an endless war continuing for many decades the manpower potentlal has been at 1ts lowest level. Day after day, brilliant students as well as 1gnorant farmers have been falling on the battle fleld. Almost every family was hit by death or sufferings. The whole social ilfe has been completely disorganized frow its traditional structure. Moral values, challenged by pressing materlal needs have been lossenIng and degenerating. Prestige of teachers and parents, or more precisely of the old generation has been minimlzed if not destroyed. It would require a tremendous effort from the government to try to bulld a long-range program in such a state of disturbances and inatabilities. And as long as the South Vletnam survives a forelgn Invasion, coclal iffe is to be promoted toward a better future.

It is with the purpose of contribution a tiny part toward promoting the achlevement of the young students in high school that this short essay has been written. The proposed guldance program In Chapter IV would provide as experimental guidelines for those who bear the responsibility to Implant this nei field of activities in V1etnamege high schools. 
In order to bring the proposed guldance program into reallty, recomendations are made as follows:

Recommendation I

The school should recelve additional funds for starting guldance program to provide for such expenses as personnel payment, off1ce facilities, public relations and Information on pup1ls.

Implementation

W1th the increased budget for education which should double in four years, the government should support the guldance program in the anticipation of Increased manpower to be Invested in economic development. F1ve percent of the school budget would be necessary to pay at least one counselor for each high achool (w1th an average of 1,000 students), to arrange his office, to buy testing materials and other facilities. The guidance service also needs to print Informative documents for teachers and parents and for pupils' records.

Recommendation II: Training of Counselors

As qualifled trained counselors are not avallable at the present time, a special one-year training program in the field of guidance should provide in the immediate future. The Faculties of Pedagogy of the Universities of Salgon, Hue and Cantho should provide teaching staff and factlitles for auch a program.

Implementation

Teachers in high schools could be candidates to the tralning program. They must be chosen from among teachers who have the conf1dence of the rest of the staff members. They should have: 
a. An outstanding degree of personal adjugtment.

b. The desire to secure adequate guldance training.

c. The ability to be effective in face-to-face relationohipe with pupils.

d. An Interest In paychology, soclology, ph1losophy, and In regearch.

e. The ability to get along with others.

f. Reasonable freedon from blases and prejudices.

8. A background of successful teaching. 1

After training, teachers ohould assume full-tine the function of counselors in the school. He should be able to take the Inftiative for the gutdance program in the school wh1ch should emphasize educational and vocational as well as personal guldance.

The temporary use of teachers as part-time counselors 18 not recomended because of the heavy load of counselees. W1th an average of 500 studente or more, a regular counselor could not keep up his work, If he has to teach part-time. V1ewing the beneficlal outcomes offered by guidance services in a school, it is worthwile to have one or more teachers off. The shortage of eccondary teachers would be remedied by Increasing teaching hours from 16,18 to 24 or 30 hours per week with Increased salary. The reason for choosing in-aervice teachers as candidates for one-year counseling training in the Imediate future is that they have more experience in dealing with etudante than do candidate etudent-teachers.

${ }^{1}$ Clifford B. Erickson and Glem B. Sulth., Organleat1on and Admintetration of Guidance Services, (New York and London: MacGrarm H111 Book Company Inc., 1947) 210. 
For the training of one year, Dr. Raines' proposal of guldance program (mentioned in Chapter IV) would be practical. According to charles W. Ryan, I would suggest candidate counselors have more professtonal study and preparation than he suggested in:

a. Developmental and educational paychology;

b. Counseling theory and procedure;

c. Group theory and procedure;

d. Educational and peychology appraieal;

e. The legal and professional ethlcs of counseling in education; and

f. Supervised experience in practicum and internshlp. ${ }^{2}$

This entire progran should be based on the following principles:

a. The program ahould be planned In consultation with the members who are to participate in $1 t$.

b. The program should attempt to reveal desirable practices and activities now being carried on in high schools.

c. The program should attempt to find out and butld on the Intereet of teachers.

d. The program should permit theory and practice to be: carried on at the same time.

At the present time some courses such as Introductory Course, Counseling Techn1ques and Procedures, and Organ1zational Relationship of the Guldance Program ahould be Introduced in the Faculties of Padigogy In order to help student-teachers get acquainted with the guldance program.

${ }^{2}$ Charles W. Ryen, "Preparation of Counselors in Ohio Cathollc School"." Counselor Education and Supervis100, v11 (1968) 119. 
In the future, when guldance serviees have proved their utility in high schools, qualified counselors should have four years or more of college tralning with counseling as the major field.

The guidance program is quite new in Vietnamese high shools, and needs an effective administrative guidance personnel. In fact, wthout administrative encouragement and leadership, it is diffcult to enviaion the success of any guidance activities according to Strang and Morris, the adminletrators have been considered the most Important person In the development of a guidance program as the adminlstrator of the school 1s, by firtue of his position, responsible for the guidance program in that school. ${ }^{3}$

Recomandation III: The School Nurse

The Importance of the school nurse was noted by Mortensen and Schwuller. The fact that in most schools, the nurse was the first to be h1red after the regular echool personnel was indlcative of her velue a a member of the guldance personnel. Her functione Included: 4

1. Providing information regarding the phyelcal health of a pup11 in order that teachers, parents, and administrators may better understand the child.

2. Making routine inspection of pup1ls who are reported 111.

3. Maintain health records.

\section{Implementation}

The school nurse could be provided by the Provincial Heelth

${ }^{3}$ Ruth Strang and Glyn Morr1s, Gutdance In the Clasaroon (New York: The Kackilian Company, 1964) 16.

4 Mortensen and Schmuller, p. 149. 
Service. She could be a faculty member of the school but would remaln attached to the Health Service for adminlatration. In som high achools, nurses have been avallable but they were not trained to cope their techniqued with guldance program.

Recomeendation IV: The School Soc1al Worker

As defined by H.W. Smtth, the school soclal worker has, through tralning and expertence, secured unlque skills for helpling children who experience difficulty in using the resources of the school effect1vely. Functions of the woclal worker are:

1. Case work Involving an Individualized approach to underatanding and aesisting In modification of probleme of adjustment through an exteneive knowledge of human behavior and gkill in interviewing.

2. Skillful utilization of comonity resources in the process of working with ch1ldren and parents.

3. Consultation services to staff members concerning child growth and development and problems of adjustment.

4. Continuous collaboration with tenchers, sdministrators, and other personnel in gathering and sharing information about students designed to modify or solve atudent adjus tment. 5

5H.W. Salth, "Pupll Services," School Soctal Work, Washington, D.C. I U.S. Department of Health, Bducation and Welfare, (1964) 19. 


\section{Implementation}

The Provincial Social Work Service could provide social workere to aselat Individual children who show environmental or soctal maladjustment. W1th the war, young delinquents are natural products of broken homes. They need to be handled and renolded.

Recolmendation V: The Paychologist

The paychologiet should Included in the guldance team. AccordIng to Mortensen and Schmuller the chlt functions of the school peychologiet are generally followed:

1. Perforwing those taske related to diagnosis and remediation of learning problems which may heve been manffest in lack of educational or personalsocial adjustment. He is skilled in the use of paychological testi.

2. Handling roferrale to other communtty agencles.

3. Serving as a consultant for in-gervice training.

4. Working wth parants to Improve relationships between parents and children.

5. Providing speciallzed services for handlcapped ch1ldren. 6

Implementation

At the flrst step of guldance organization, where no avallable qualifted psycholggists are offered, monks, prlests and mintsters

Gorteneen and schmuller, p. 149. 
could serve as ploneer psychologista. In each district or province In Vletnan, there are alway parishes or buddhiet congregations which Influence more or less the bellefs, cuetoms and behaviors of people. If they agree to cooperate with the gchool in the fleld of guidance, that would be the first communty resource to assume the responsibility of peychologists.

\section{Recommendation VI: The Classroom Teacher's Role in Guldance} Services

The classroom teacher should play a vital role in the program of guidance servicea because he 10 most directly in touch with Individual student over an extend period of time.

Farwell and Peters contend that most authorftes, most administrators, most guldance specialists, and most teachers would agree that the classroom teacher occupled a frontline position in all aspects of educational endeavor. 7

The classroom teacher could be an academic advisor by helping student select those school subjects and extra-class activities which would help hin to achieve his educational and vocational goals and which seemed to contribute most to his social and emotional developm ment. 8

Implementation: Differences between the guidance functions of teachers and counselor should be made

Downing stressed that the teacher was skilled in the techniques

7Ga1l F. Farwall and Herman J. Petera, "The Guldance Function of the Classroom Teacher," The Clearlng House, xxx (December 1955) 231.

8 Merle M. Ohlsen, Guldance Services In Schools, (New York: Harcourt, Brace and World, Inc., 1964), 417. 
of Instruction and the counselor was adept In the use of the tools, materials, and techniques of the gutdance worker. 9

In 1966, Arbruckle polnted out that "the teacher and couneelor are two different professional workers, each unlque in his own right, and while the good teacher is a 'guidance worker', he io not a counselor."10 It is Interasting to note here the responsibility of the teacher as a "guidance worker" who would be aware of his linftations and perform such fumctions within those IImftations:

1. Providing a wholesome clasaroom atmosphere;

2. Knowing and creating wach pup1l as a person, Ineofar as this is posalble in large classes and highly departmantallzed schedules;

3. Help1ng each pup1l to better understand h1melf;

4. Wetching for early aymptoms of maladjustment, elther phyelcal, mantal, or emotional;

5. Ut1lizing classroom situations to give Individual pup11s experience In IIving and working with others;

6. Enlisting services, if need be, of the nurse, counselor, vice principal, or vlalting teacher so that pup1ls can be helped before the situation becomes sertous. 11

${ }^{9}$ Lester N. Downing, Guldance and Coungeling Services, (New York: KeGraw-H111 Book Company, 1968), 417.

10 Dugald S. Arbruckle, Pup 11 Personnel Services in the Modern School, (Boston: Allyn and Bacon Inc., 1966), 134.

11 Alchard Harbour, "The School's Role in Guldance," Guldance Department Hundbook for Adminiatrators, Coumselors, and Teachers (San D1ego Public Schools, 1962) 29-32. 
Fullmer and Bernard pointed out that the major job difference between counoelor and teacher was in the dally performance in the school. They explained that teacher-pup1l contacts vere usually relnforced as euperior-aubordinate relationsh1pa. Quite the contrary was true in the counseling aftuations; $e .8 .$, the counselee came to the counselor in an adnitted subordinete or weaker role. The counselor was viewed as an authority, at least with respect to the concerns which the counselee brought to the conference. This necessitated the counselor not to exploit or reinforce the authority role. This according to Fullmer and Bernard, was the essentinl varlable that distingulehed counselor behavior from the teacher. 12

Recomendet1on VII: The Counselor's Role

The important role of the counselor should be adjusted to the V1etnamese social structure.

\section{D1scussion and Inplemantation}

Since the establishwent of the Vocational Bureau by Frank Parson In 1908, the term guldance and counseling have been mlaconcelved and the role of counselor misunderstood to sove extent. "Counseling is one of those words that everybody underetands but no two people seens to understand in precisely the same way."13 The fact 1s that the term "counseling" der1ves from "guldance" and through evolution, "guidance" was changed from 1 ts orIglnal meaning. In Its early days, "guidance"

${ }^{12}$ Dantel $W$. Fullmer and Barold W. Bernard, Counseling: Content and Procese (Chicago: Sclence Research Assoctates, 1964), 89.

13 Leonn E. Tyler, The Work of the Coungelor, (New York: AppletonCentury-Crofte, Inc., 1961), 1 . 
was Inseparable from another word-vocat1onal- and when one talked "gutdance", he meant vocational guidance.

Today guidance Involves throe areas of counseling: educational, vocational and personal as an inseparable trio. In reality, experiences have shown that one or two of these roles prevall over the others.

In the Unfted states, most of the counselore in sentor high schoole spend the largest of thatr tiwem-between 75 and 95 percent-on educational programing and college advielng, and much lese tiae for counseling in the personal fleld, 14 (one hour per semeater, reported Lytton). The reasons given for this emphasis are that much counselor time is consumed in clerical and administrative duties, and sudents' dietrust of counseling for personal probless. The only counseling service appreciated by students is the help in the selection of courses. Studente saw councelors as more concerned with dally educational planning rather than with private peraonal probleme. They expected them to intervane when they have a low grade or "trouble with the teacher" and ask for a chenge of schedule wth another teacher. Frequently "counselors jlelded to thie preseure and conformed to expectations." 15

Parsonal experiences of the writer whle doing her Internahip at some public Junior and sentor high schools in Portland, Oregon, confirmed the role of counselors viewed by Lytton.

\footnotetext{
${ }^{14}$ kugh Lytton, p. 13-14

15 Ib1d., P. 15 .
} 
In V1etnam, the approach to personal problems la quite different. By tradition and culture, relations between boys and g1rls have long been regarded as bad manners before vedding. Though Western influence has been altering rigid custows for decades, many of fantlles still restricted thelr daughters' relations with boys. Good families surveyed the1x daughter's reading 11terature Including private mall. Questions about sex understanding in 1te mildeat form have never been discuseed openly in family or school.

During recent years, the war has affected traditional habits and cuetoms. The high cost of living, broken homee and war casuallties have Increased youth delinquency. In the single year $1964^{16}$, there were In the whole country 3,125 cases of young delinquente judged for thaft (65\%), prostitution (9\%), fight (7x), running hone (9), and othere $(14 \pi)$.

The real number of young delinquents who were arrested as violators but not judged could be ten times higher.

Delinquency should be a concern for counselors in Vietnamese high schoold in order to re-establish the wental equilibrium in youth who are loelng the benafits of education becauae of cocial instab1lity. It is the most delieate task for counselore to convince the youth of the benefictal and productive effect of a good education while soctal situation exists in wich moral values and individual talente often fall to establioh a fair vell-being for everyone. In a

16 vu-Quang-Dung, Thu Duc Correctional Center for Juvenile Delinquente, Master Degree Thesis In Adninietration, University of Salgon, (1969), unpubliahed. 47. 
soclety where fortunate adventurers could become powerful generals and high-rank officials, where black market businese prevalled over governmental administration, where prostitutions developed and prospered legally, where dance halls and snak-bare for forelgn soldlers overwhelmingly outnumber schoole and hospitals, where traditional beliefs and custom were ridiculed, it would be a difficult but necessary task for the counselor to try to endow students with educational and ethical tools for an improvenient of their social adjustment.

Thus the role of the counselor in V1etnamese high school should be modified and adepted to the present social status. Not only should the counselor deal with educational and vocational guidance but also he ahould reaseart the traditional apirit which valued an education.

Enlightened by the above consideration, a tentative role of counselor in high school to to be suggested as follows:

1. According to Martha Ellison, cocrdinator of Curriculum Development:

The term "counselor" Indicates that pexeon within the full-time staff of the school who is charged with helping studente in an organized way in selecting and interpreting their experiences, in the formation of healthy attitudes and in thatr growth toward Intellectual, anotionel moral and physical maturity. 17

So, the counselor should have a clear perception of his role. It 1s true that the guldence program is quite new In VIetnamase high school, he w11 encounter many situations In which 1t appeare that

$17_{\text {Ib1d., p. } 51 .}$ 
nelther his elgniflcance nor his contribution is recognized. Kaplan pointed out that the effectivenese, and professional competence of the public counselor is recelving growing attention, coment, and investIgation Irom numerous and diverse sources. 18

As Bea J. Amundson and Frieda $T$. Rosenblum have quoted a typical comments of firat-year counselor in their study on "The Classroom Teacher Percelves the Counselor," as Lollows:

\footnotetext{
Eatabliehing and developing a gutdance program and gaining acceptance are very difficult... My greatest problem is astablfghing rapportudth the teacher and the princlpal.
}

Bven In Amarican, where guldance program has been Introduced in schoole long time ago, often the teacher atill looks down on the counselor as somebody who got a job simply by taking a course or two and having the ability to "get along with kids." In this case, Fullmer and Bernard suggested that "one of the ways in which the counselor can Improve his effectiveness is to recognize and accept the teacher's occasional vien of hin as an interloped." 20

2. The full-time coumselor hould assume the role of "director of guldance". He has the admintatrative and managertal reoponsibilities In:

18 B.A. Kaplan, "The New Counselor and He Profesatonal Problems," Pereonnel and Guldence Journal, xoxt1 (1964) 473.

19 Ben J. Amundson and Frleda T. Rosenblum, "The Claseroom Teacher Percelves the Counselor," The School Coungelor, xv (1968) 215.

20 Fullmer and Bernard, p. 111. 
1. Procurement of fac1litles for counseling.

2. Salection of counselors.

3. Development of favorable attitude toward the guldance program on the part of principals, teachere, pup1ls, parents, and citizens.

4. Clarffying the guldance functions to be exercleed by the counselor.

5. Distribution of guidance dut1es, e.g., butlding the guidance 11brary, operating the testing program, atc.

6. The plen for collecting and diseeminating occupational Information.

7. Planning the pup1l interlvew program w111 full respect for the daily schedule of instruction. 21

As guldence director the role of the counselor 18 to advise the principal in establiahing the guldance program; he is the person who w11 be consulted by homeroom and classroom teachers for assietance in rendering guidance services. He vill assist then ia interpreting teat results, evaluating the varlous items of the cumulative records, and halp then to lead their pupils in the Idantification and attempted colutions of their problens.

3. To Fullmer and Bernard's point if view, psychology ranke high on the study achedule of counselors. "Counseling procedures have strong roots in peychological assesement, peychoanalytic peychology,

${ }^{21}$ Percival W. Hutston, p. 633. 
and educat1onal peychology with its emphasis on both the 11kenesses and unlikeneses of individuals."22 The counselor should be a specialist in child and adolescent paychology, in effecting learning and change, In human relations, and soclal adjustwent. He w111 collect, organize and Interpret Information appropriate to an understanding of the pup1l's abilities, aptitudes, Intereste and other personal charactertetics related to educational-occupational planning and normal personal-soctal adjuetnents. He snould cooperate with the peychologlst to work out solutions for abnormal behavior.

4. The counselor should be Involved in curriculum work as an Interpreter of the changing needs of youth in the comandty. He acto as a conoultant for change in the curriculum. He w11l provide adminietratore and teachers with information about individual pup11s or student groups in planning school programs and curriculum to fac1litate the full development of student potential. He also provides guidance Information which mey be used in evaluating the school's program in term of 1te ability to develop human potential.

5. The coumselor should help in the orientation of parents to ensure greater understanding of the educational program; he should plan visits to parente to aselet tham in better understanding of their children. For that purpose, he consults and counsels with parents, Individually and in groups.

6. The counselor should be deeply Involved in moral gutdance besides educational and vocational guldance. He should we his prestige,

22 Pullmer and Bernard, p. 29. 
perconaltty, and knowledge as model for pup1le to judge the ethics of their own behaviors and to endorse ethical responsibility. He should provide Individual conferences helping students solve the1x pereonalenotional problems. He particularly paye attention to studente whose fantlles heve been broken or directly affected by the war. In this role he should cooperate with the social worker and teachers to discover the enotional disturbances which might be the causes of delinquency and dropoute.

7. The counselor should provide group activities to:

1. Orient atudents to educational opportunities and procedures at varlous grade levela,

2. Inform them about occupational and wiltary gervice opportunities and requirements.

3. Assiat them in the making normal personal adjustments and social contacte.

8. The counselor thould provide placement services for Individual students to aeniet them in making appropriate tranm1tions from (a) one school level to mother, (b) one school to another, (c) school to employment. The counselor should assiat poor atudents in obtaining flnanclal atds to continue their educational program such as scholarohip and part-time jobs.

9. In the firet phase of gutdance developwent, the couneelor w11 face the difficulty of explaining to pupils how coumseling may help them. V1etnamese atudente, particularly glrls, have not been used to exprees their personal feelings, thingings or "troubles" wth 
teachers or parente. They are too shy to make confidences and ashamed to disclose their enotional reaknesses. On the other side, they begin to sense the ladependence of adolescence and may hesitate to talk to counselort. So, the counselor should create a climate conducive to counseling. To be percefved as a helping person in an educational, vocational and personal way, he must use every opportunity to enter the pupil's world. He ohould appear in the hall as in the playground and be viewed as a friendly "advocnte" to studente and complementary flgure to instruction. To show to students how he can be helpful, the counselor should use:

1. Slides, mimeogrephed booklete and classroom talk to explain the counseling process.

2. A saries of posters showing the pupils how to anke an appointmant and Indicating poselble positive resulte.

3. Clase vielts to present the materiale with time allowed for discuse1on.

4. To win the trust of counselees, the comselor should sosure studente that he will not disclose thetr personal problems to whoever, even to their parents. Th1s is an 1mportant aspect of his confidential role toward counselees. Recommendation VIII

The organization of gutdance eervices in high, echool should be gredual according to personnel and phyelcal fac1lities avallablitty.

\section{Implementation}

\section{Flret Stare:}

1. Diesemination of guidance materials among principels and 
and tenchers.

2. Special training of counselors (one year) chosen from among teachers who fulfill requirements and are volunteer to follow the training program.

3. The trained counselor works full-tine at any average population achool $(500-1 ; 000)$. For heavy load achool two or more counselors are required. He assubes the matn guidance activities.

4. Creation of homerooms where students feel fres to discuss thetr own problems with the teacher in order to sat1sfy their needs. It should be a place where there is no acadentc pressure, and where the motivation 18 more raalistic. A perlod of time--at least a half hour-1s to be allowed twice a week to homeroom for discumsion. Problems of school adjustrents are to be encompasaed in the homeroom program. Selaction of the teachers assigned to homeroom should be based on f1tness.

5. Classroom teachers should be trained in guldance dulmg summer workahop to be arare of and to partlctpate in guldance act1vities.

6. A nuxse is necessary to provide information about atudent's bealth.

7. Chart VI shows the organization of guldence services during the first stage in an average high school of 500-1,000 students. 


\section{CHART VI}

ORGANIZATION OF GUIDANCE SERVICES IN HIGH SCHOOL

FIRST STAGE

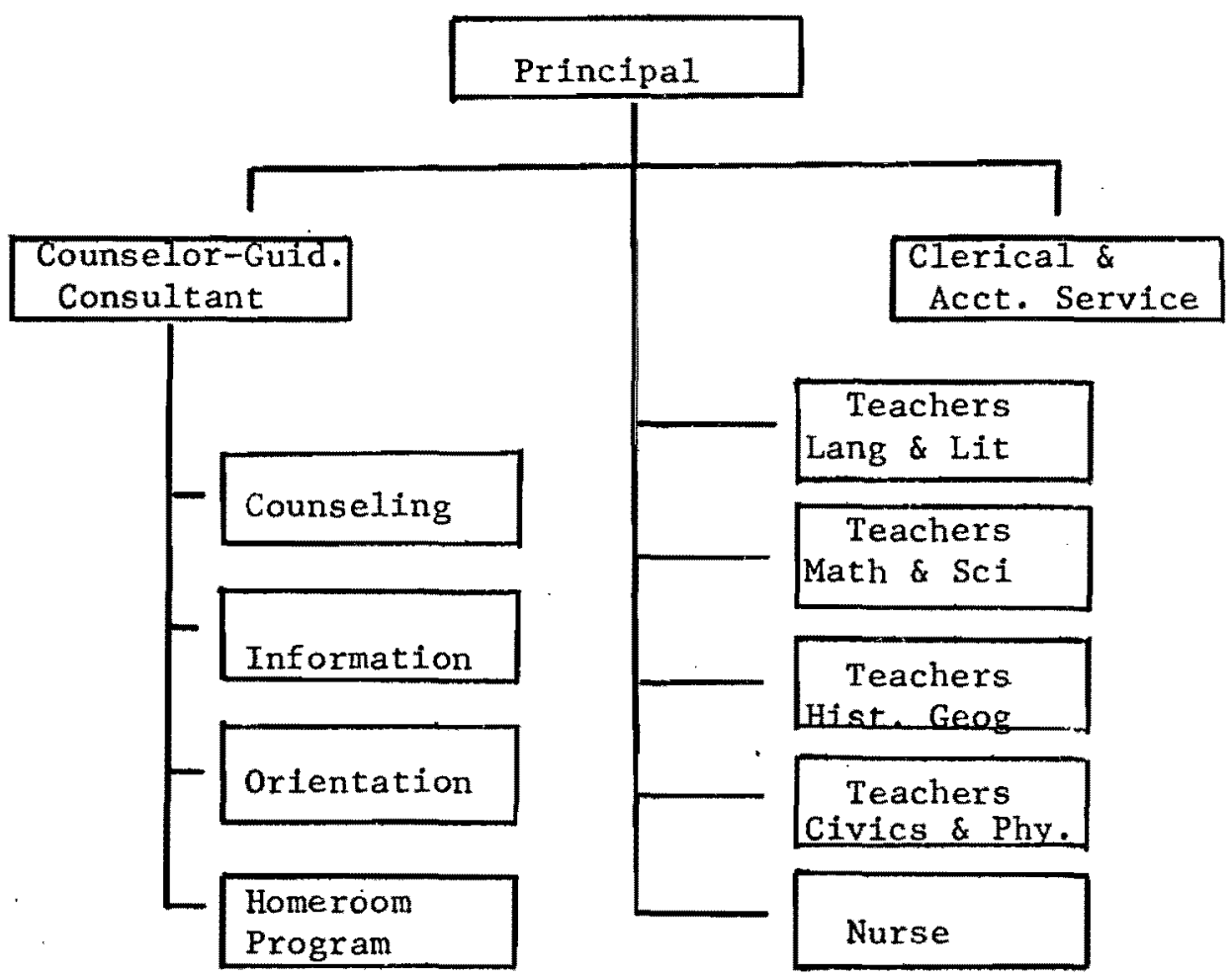




\section{Second Stage:}

1. The counselor is sesigned the function of director of guidance.

2. Organization of Appraisal service (See Chart VII)

3. Teating materials should be provlded to school. Different1al Apt1tude Tests (DAT), School and College Ab1lity Teat (SCAT), Tests of Academic Progrese (TAP) or a almilar teat adapted for V1etnamese use could be designed by the Testing and Guldance Center. This center has developed a model Pup1l Inventory Record for all public secondary schools.

4. A competent well-trained social worker 18 to be added to the School Guldance Personnel.

\section{Third Stage:}

1. Organization of the placement and Follow-up Bervices.

2. Service of Peychologist 18 to be Inoured ef dietrict level (aee Chart VIII).

3. Relnforcement of the Counseling service by qualifled counselore to reduce the rat1o of load from 1: $500-1,000$ counselees to 1: 200-300 counselees.

\section{Recomendation IX}

The att1tude of teschers in high school should be changed to fit the new guidance program. "The teacher-pup11 relat1onsh1p should be characterlzed by warmth, acceptence and friendliness." 23 The trad1t1onal "d1stance" between teachers and students should be transform

$$
23 \text { Downing, p. } 47 \text {. }
$$


CHART VII

ORGANIZATION OF GUIDANCE SERVICES IN HIGH SCHOOL

SECOND STAGE

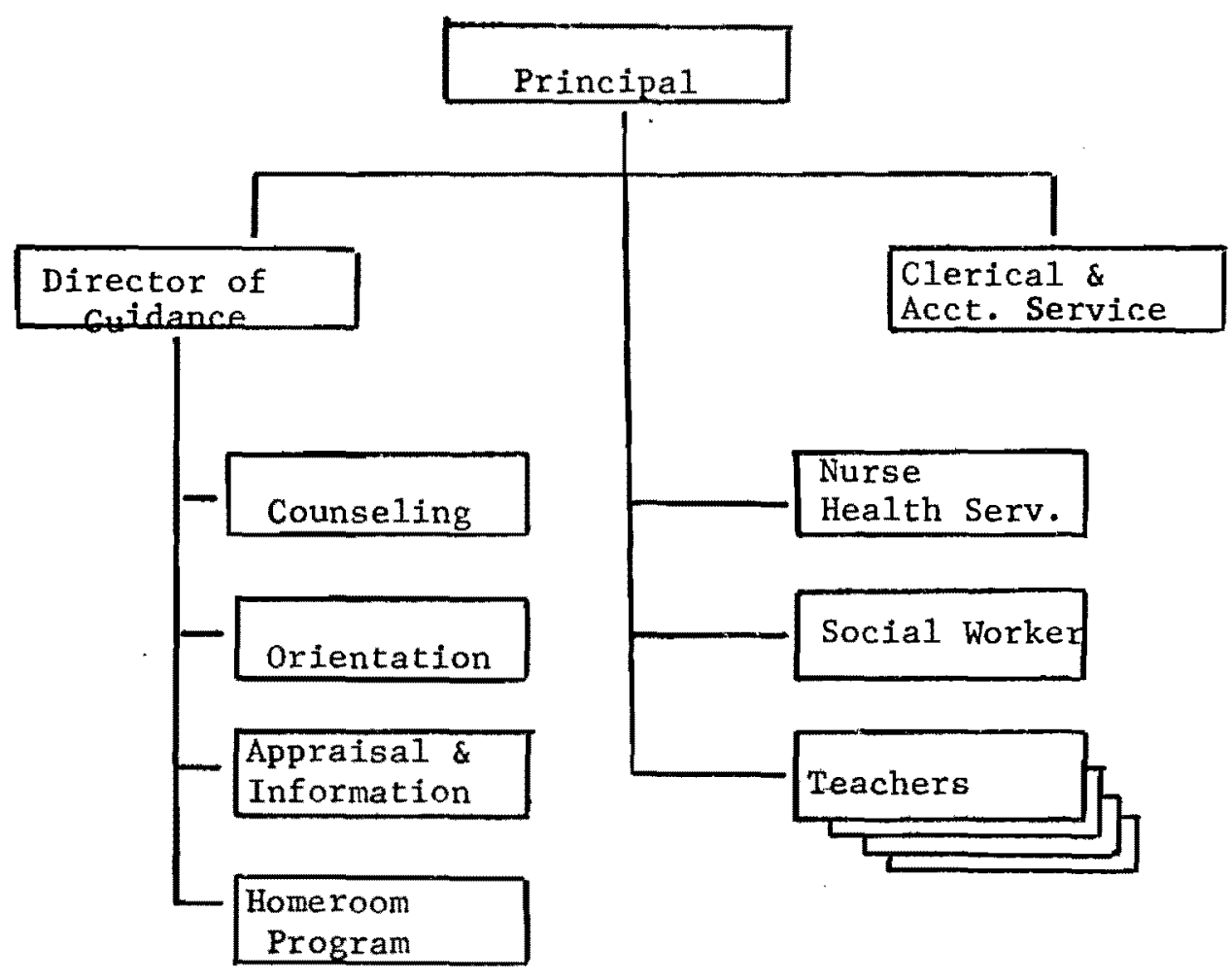


CHART VIII

ORGANIZATION OF GUIDANCE SERVICES IN HIGHER SCHOOL

THIRD STAGE

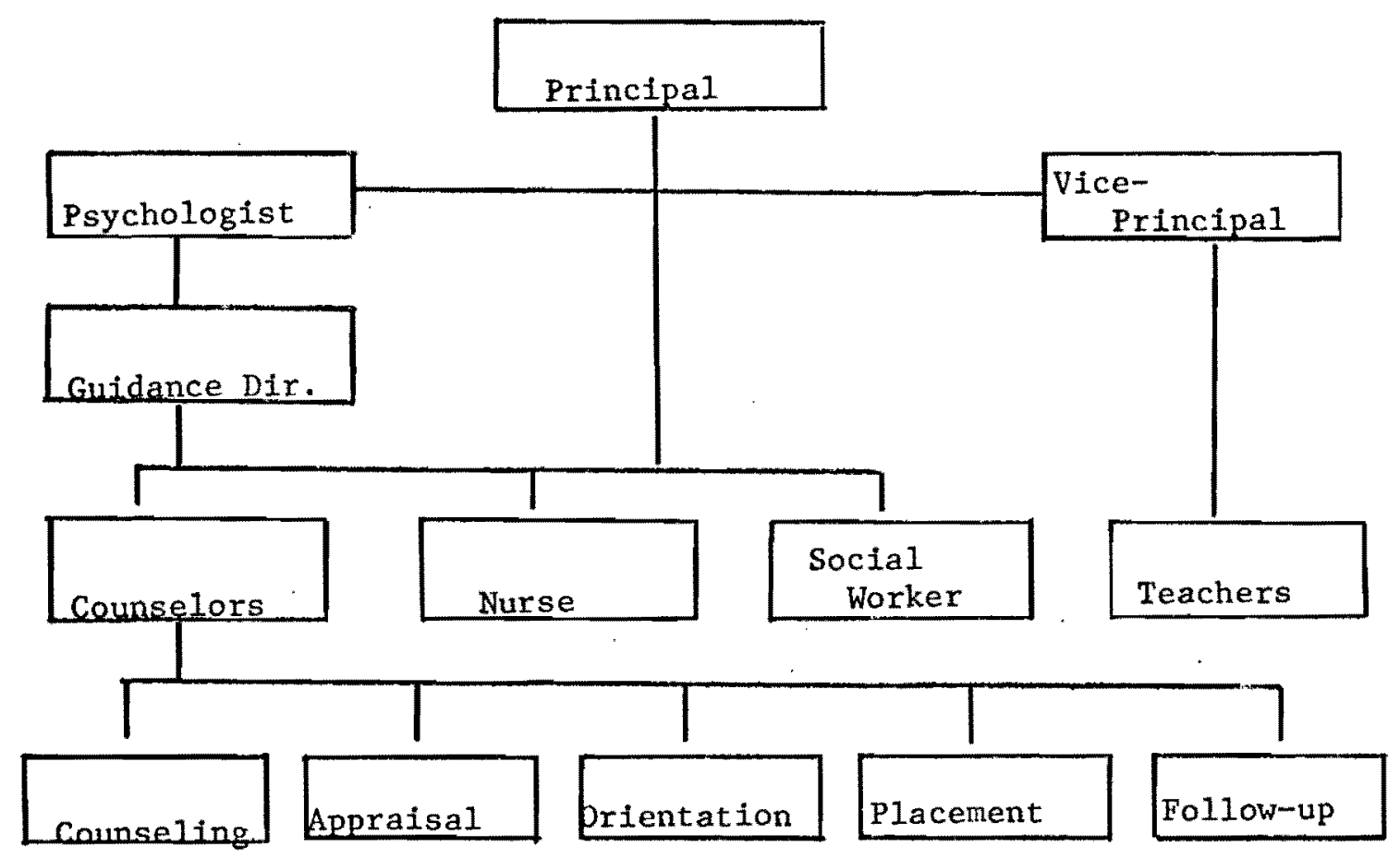


In a warm Interaction conducive to better understanding of students and to assisting them for future social adaptiveness.

Implementation

Democratic way to approach teaching; permisalve attitude of teachers toward arguments and discussions; all teachers should attend an in-gervice tralning in guidance. 


\section{CONCLUSION}

A guldance program at the high school level has been formulated by the writer to help Vietnamese studenta Iearn more about themielves as Individuale and improve learning for a better achievement. For many decades, the Vletnamese students have been learning by rote all the literary knowledge good for aduinietrative employmant and with teachers who never pald attention to personal problews or Individual ab111ty. This had led to a great shortage of specialists necessary for economic development and to a mass of pasalve citizeno who lacked Inftiative and creative thinking ablitty for solving personal probleme. No assiatance has been avallable to students who needed help to contInue their education, nor was there any orlentation to vocational planning. A vaste of manpower through an obsoles syeten of education has been an obstacle to progress.

Concurrently with the new trend of educational reform requested by national demand, the writer has tried to work out a propar way to aselst the praiseworthy and studious Vietnamese boys and g1rle who are attending high schools. They nead to be provided with a altuation in which they are free to explore thair attitudes and tha1r 1deas within the privacy and security of a confidential interaction with the couneelor. The etudent may come out of this interaction with the awareness of a self-evaluation and knowing that only he can choose a 
course of action and that only he can accept the responsibility of his cholce. The new step is to be encouraged. And the counselor is there to ald him advance toward greater steps of self-acceptance and self-understanding. As he realizes that his needs wight be satiafied, his emotional disturbances released the little atudent sees himself as having a significant value in society and decide to walk with more confidence and ardor.

The wrtter has proposed a guldance program for traditional achoola. In the tentative plans, differences in culture and soc1al structure, as well as local conditione, have been discussed. Different guldance servicea to realize the main objectives have been proposed. Enphasis has been made on the role of the coumselor, principal actor on atage. Ploneer in a new educational syetem, the V1etnamese counselor needs to know his ability, his fitnese to youth problems, and the 1imits of his responsibilities. For this purpose, h1s role was well defined and h1s place well marked in the school structure. There would also be the Implementation of the entire student personnel staff including the 8 chool nurse, the social workar and paychologist at distriet level.

Because of the shortage of guidance perconnel at the present time, In V1etnam, the guidance program is to be realized in three steps wth gradual implementation of different services. However, the success of such a program would depend largely on the support of the government and the parents, on the changing attitude of teachers for a better relationship between them and the atudents, and on the evolution 
of school programs which emphasize broader and more practical goals for the etudent. "It would not be too much to say that on the success or fallure of our guidance program, hangs, In all probability, the success or fallure of our syetem of public education." 1

$1_{\text {James B. Conant, quoted by John W. M. Rothney, "Coumeling }}$ Does Help!", The Vocational Guldance Quarterly, v1 (Fal1 1967) 15. 


\section{EIXIOGupin}

\section{A. books}

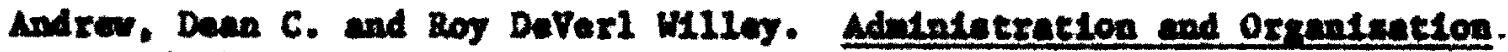
of the Gusdnece Progrea. Hew York: Anrpar Brothere, 1958.

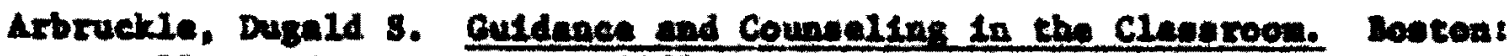
Alyn and Bacen, Inc., I961.

- Pupll Perromel services in the kedern geboel. Boston: Milya and Bacon, Int. 1966.

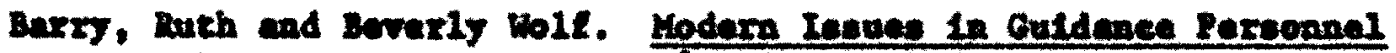
bork. How Iexks Teschere' College, 1963.

Beck, Carlton E. InLlepophtenl Ioundattons of Culdence. Inglowood

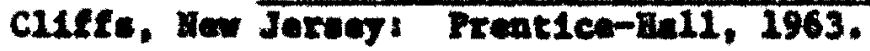

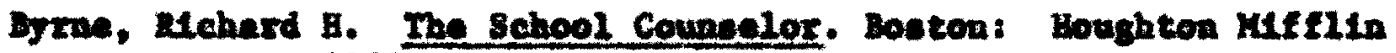
Company, 1963.

Debbo, Kyron, Vera Ioung and John A. Carpentex. The Poxcholorteal

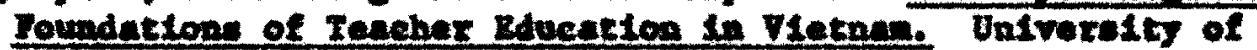
Southera Califorala: Center for International Dduention, fehool of viveration, 1969.

Downing, Leetox 1. Guldenee und Couneeling Services. How York: Megraw-B111 Book Complay, 1968.

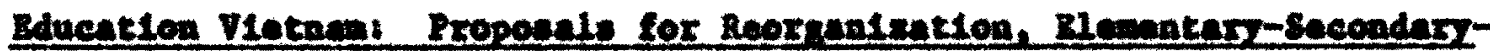

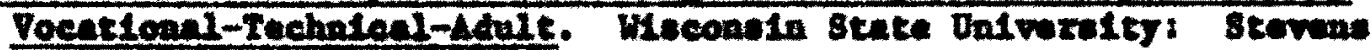
Polos seudy Tean, AD, 1967.

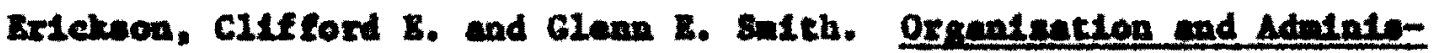

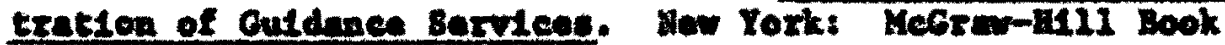
Compers. Inc.. 1947.

Iromileh, Cliflord P. Guldence Sorvlces in sebools. Wew York: HeCrum-Blll Book Cexpany. Ine., IOS8.

Fullare, Dantel $W$. and Harold W. Barmard. Couneelingt Content and

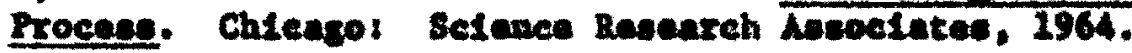


Good, Carter v. Eegentlale of Educational Reeenrch. Hew Tork: Appleton-Centuzy-Crofte, 1966.

Cordon, Ira J. The Teacher a a Culdence Norker. Nev York: Harper \& Brothere Publiohere, 1956. 1966.

Studyine the Child in School. New Yoxk: John WLley,

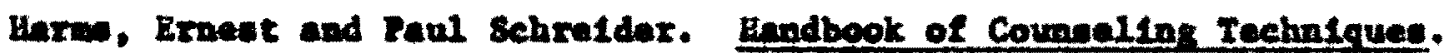
How York: The Yackilian Company, 1963.

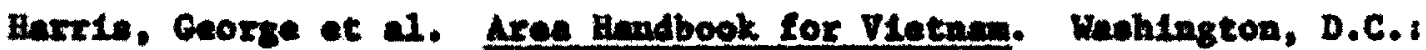
U.S. Coverment Frinting Offlce, 1962.

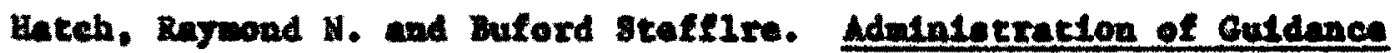
Servees. Englewood Cliffe, Hew Jexwey: Rrent1eo-Bell, Inc., 1965.

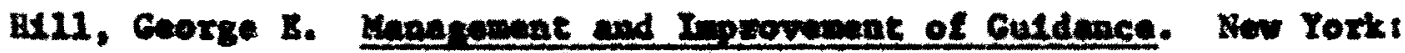
Applecen-Centeur-Crofte, 1965.

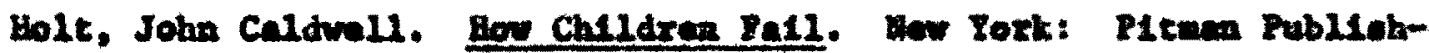
Ins Corporation, 1964.

1967. How Chlldren Learn. Hew Iorks Pltwan Publiehting Corp.

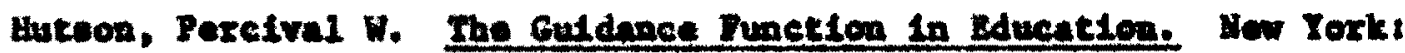
Appleton-Century-Crolte. Ine., 1958.

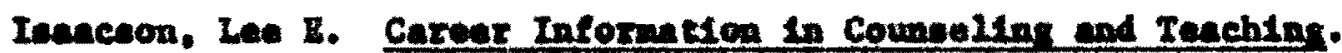
Bontoni Ally and Bneon, Ine., 1966.

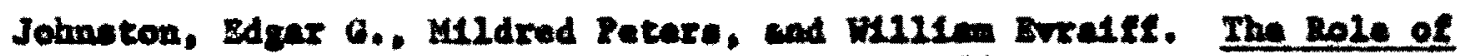
the Teseher in Culdence. Baglewood Clikfe. Hew Jereey: Preatiee-11011. Inc., 1959.

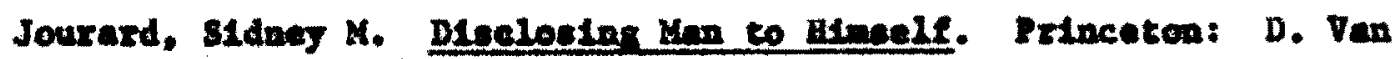
Nootrend, 1968.

Landy, Bdward and Paul A. Perry, editors. Culdance in Aerten

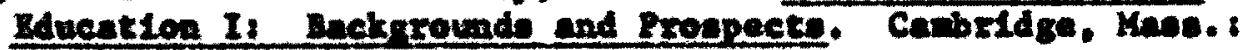
Hervard Dofvera1ty Prees, 2966.

Loughary, John H. Counsellar in Secondery sehoole. Iew Iork: Harpar and Brothen 1961.

Kebutel, Henry B. Culdenee in the Yodern Sehool. Now Iork: The . Dryden Prens, 1950. 
Mortennex, Donuld G. and Allen M. Schmullex. Guldence in Todsy's Saboola. Wor Tork: John WLley and Soms, Inc., 1960.

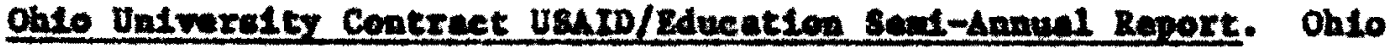
Univeralty V1etnem, July let 1967-Januaxy let 1968.

Ohto Univeretey Contrect Usarp/Educecton Sent-Annuel Regort. Oh10 Uaiverefty Vletuan, Januery Iet, 1968-July lot 1968.

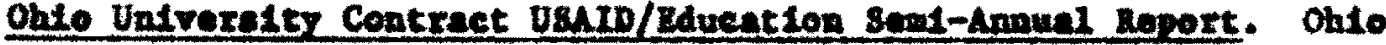
Ualverexty VLetone, July let 1968-Jemuary let 1969.

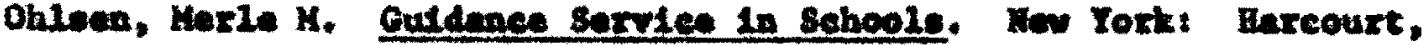
Brace and World, Inc., 1964.

Zatcerwon, C. H. Coungellng and Guldence in 8ehoole. How York: Uneper and Brothere, Ino., 1962.

Rothney, Joho W. K. Gutdrnee Prectlees and Reoulte. Mow Ioxk: Eaxpar and Ixothare Bom, 1958.

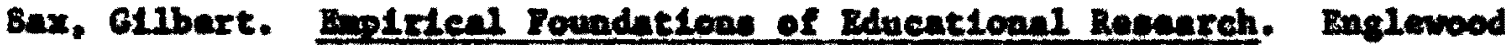
Clife, har Jaraey: Frentiee-Hill, Inc., 1968.

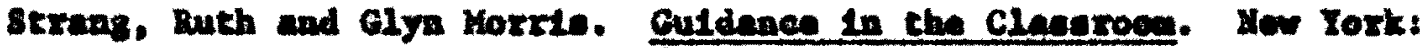
The Malkillan Comany. 1964.

Tylex, Leont i. The Bork of Couneler. Mn York: Applecon-ConeuryCrole., Inc., 1961.

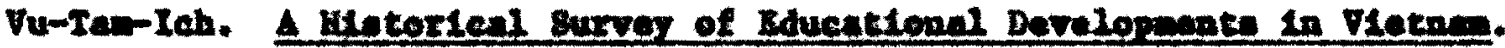
Untveresty of Kentudks: College of Eduention, 1959.

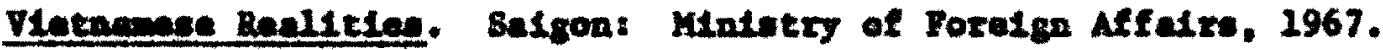

Wright, B.D. Prectich Enodboek for Group Guldance. Chicagot Satence pesenreh neseelaten, Ine.. 1948.

\section{B. ARTCLEs}

Amertean Sehool Counnelor Aosoclation. "Tantative statement of Polley Lor Secondery School Counbelore." The Amerlen Perponel and Guldence Journil, DoxII (October 1963) 191-203.

Amudeon, Ban J. and Frieda $T$. Pesenblue. "The Claseroon Tescher Pereelves the Counbelor," The Sehoel Couneelor, IV (January. 1968) 215-219. 
Carey, Rlahnrd W. "student Proteat and the Councelor," Rereonnel and Guldence Journel. XXXXVIII (September 1969) 185-191.

Dewal, Onker s1ngh. "Philowophy of Culdance: V10w fron the Bast," Perconnel and Culdance Journel, XxxxrII (Oetober 1968) 117-119.

Dilison, Nartha. "The Counelor as seen by a Currfeulim Development 8pectal1nt," Couneelor Iducintion and Superviston. VIII (Fall 1968) $66-67$.

Yarma11, Cad1 7 . and Herman J. Recers. "The Guldance Junction of the

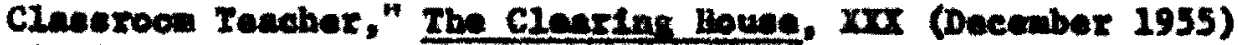
231-233.

Hoang-GLa-Linh. "The Critical stage of Edueation in Vietan," the Lational Rlemencur Princlpel, XIIV (rabruary 1965) 48-57.

Jeasen, Ralph Z. "studeat Fealins About Counsellos Belp," Rereomel and Guldince Journal, DxIII May 1953) 498-503.

Kaplan, Barward A. "The Ine Councelor and Hte Proteatoand Problems," Fereonel and Guldenes Journal, XxoxII (Janerary 1964) 473-478.

Lytcon. Exph. "School Counealor-An Outelde View," Rereonel and Guldence Journal, XxxivII (soptember 1968) 12-17.

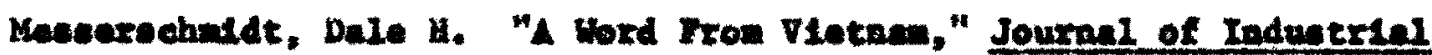
Arte Bduection, XVII (Auguet 1968) 34-37.

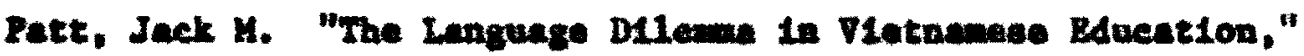
Joarzen of Mgher Eduention, Xxx (Miny 1969) 385-389.

Jane. F. Penney. "Pocational Guldance in Burope and the United States," Yocettenel Guldence Gunterly.

"Frogrese of Educhtion in Fletane during the School-Year 1965-1966," Exocesdinte of the XXXth Incernationnl Conference of Publie

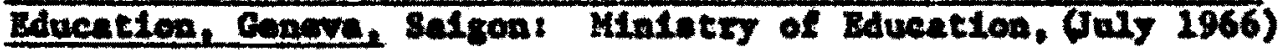

"Progreas of Bducation in Vietnen duxing the school-year 1966-67,"

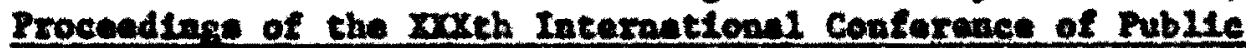
Elucatlon, Conere, Salgent Maletry of Xducation, (July 1967).

"Progrese of Bducation In V1atwen during the school-Xear 1967-1968," Frocecdiare of the worth Intermationd Conference of Public Eduencton, Genere, Selgont Mintetry of Educution, (July 1968).

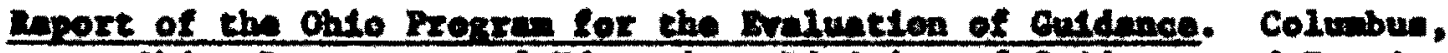

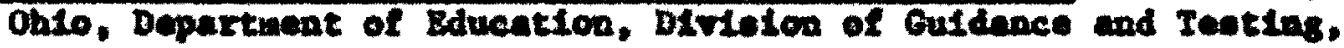
June 1963. 
"Rapublie of VLatnan: Lacetional Devalopmente in 1965-1966," Intermetsoanl Iearbook of Edwent1on, XXVIII (1966) 398-402.

"Republic of Vtetnim! Bducational Developmente In 1966-1967," Internatlonal Yearbook of Eduest1on, XXIX (1967) 476-480.

"Repub21c of V1etram: Edueat1onal Developmente in 1967-1968,"

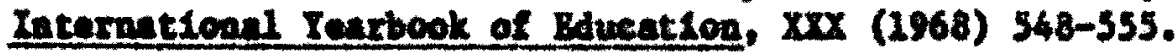

Rothwey. John H. K. "Counseling Dowe Help!" The Voentional Guidenee Quarterly. VI (Fall 1957) 15-18.

Ryen, Chaxles t. "Preparation of Counuelore in Onto Catholle scinoole," Councelor Eduaction and supervielon, VII (Winter 1968) $119-123$.

"Schoole in VLetnon," Vewneek, (Auguot 28, 1967) 55-56.

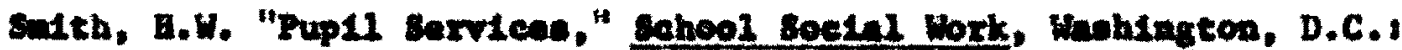
U.8. Department of bealth, Bducation and Welfare, (2964) 19-23.

Stubbins, Joooph. "The Rolitics of Counealing." Perconnel aed Guidanes Journal, wocorIII (Apre1 1970) 619-627.

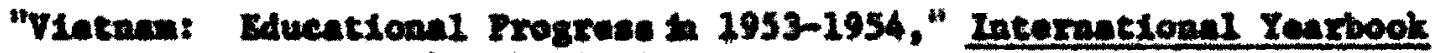
of sduenten, (956) 383-388.

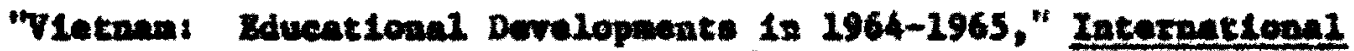
Yearbeok of Bducation. XxVI: (1965) 339-443.

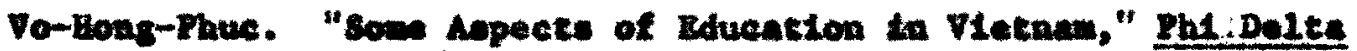
Eappen. ExxTX (Decenber 1957) 133-135.

W1L1e, Beajonde C. "The Contribution of Cutennce to the High sabool Bduantional Progran," Eereonnel end Cutdence Journal, Dov (Apr11 1957) 489-494.

\section{UtroBLISHED MTERTLS}

Knox, Denuld K. "The Caee Lor Comprohemelve Bdwatelon in V1etnen," speceh dellvared at the rotary Intornational club of salgon, (Decambex 1969). Mtwoograpbed.

Hguren-Due-Keta. "A Deston for the Bveluation of student Progrese in Vletwanece secondary sehoole," Unpublinhed doctorel diesertetion, Untveratty of istmeuse, 1969. 


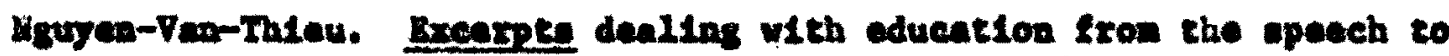
VLetnamee people delivered on Oetober 6, 1969. Mineographed.

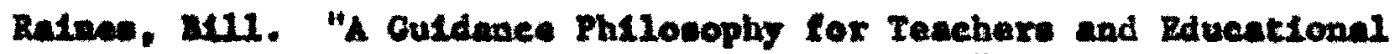
Frecticen Which Raflect that PhL10sophy," Pronentetton wade to the studente of the Feulty of Padigory, Unfveratty of llue, (Apr11 1969). Htmographed.

- "The Developant of Guidance and Coumeling Programs in VIetranene Hgh Bchoole," MClnoographed.

- "Working a a Teacher Educator in a Developing Country," Ohio Untvarafty Contract Usum/zducetion, Sexi-Anaual Roport, (Jasuary-June 1969).

"Thu-Due Demonetration Secondary school," Jaculty of Pedagog, Univeralty of 3ntgon. Mineperaphed.

Vu-Qunag-Dung, "Thu-Due Corxectlenal Center for Juvenlie Dellnquente" Unpubliabed Mattor Degree Theolo in Adulatetration, Undvaralty of Baspon (2969). 